OPEN ACCESS

Edited by:

S. Venkata Mohan,

Indian Institute of Chemical

Technology (CSIR), India

Reviewed by:

Guangming Jiang,

University of Queensland, Australia

Katerina Stamatelatou,

Democritus University of Thrace,

Greece

*Correspondence:

loannis V. Yentekakis

yyentek@isc.tuc.gr

Specialty section:

This article was submitted to

Wastewater Management,

a section of the journal

Frontiers in Environmental Science

Received: 19 October 2016

Accepted: 27 January 2017

Published: 16 February 2017

Citation:

Yentekakis IV and Goula G (2017)

Biogas Management: Advanced

Utilization for Production of

Renewable Energy and Added-value

Chemicals. Front. Environ. Sci. 5:7.

doi: 10.3389/fenvs.2017.00007

\section{Biogas Management: Advanced Utilization for Production of Renewable Energy and Added-value Chemicals}

\author{
loannis V. Yentekakis * and Grammatiki Goula \\ Laboratory of Physical Chemistry and Chemical Processes, School of Environmental Engineering, Technical University of \\ Crete, Chania, Greece
}

Biogas is widely available as a product of anaerobic digestion of urban, industrial, animal and agricultural wastes. Its indigenous local-base production offers the promise of a dispersed renewable energy source that can significantly contribute to regional economic growth. Biogas composition typically consists of 35-75\% methane, 25-65\% carbon dioxide, $1-5 \%$ hydrogen along with minor quantities of water vapor, ammonia, hydrogen sulfide and halides. Current utilization for heating and lighting is inefficient and polluting, and, in the case of poor quality biogas $\left(\mathrm{CH}_{4} / \mathrm{CO}_{2}<1\right)$, exacerbated by detrimental venting to the atmosphere. Accordingly, innovative and efficient strategies for improving the management and utilization of biogas for the production of sustainable electrical power or high added-value chemicals are highly desirable. Utilization is the focus of the present review in which the scientific and technological basis underlying alternative routes to the efficient and eco-friendly exploitation of biogas are described and discussed. After concisely reviewing state-of-the-art purification and upgrading methods, in-depth consideration is given to the exploitation of biogas in the renewable energy, liquid fuels, transport and chemicals sectors along with an account of potential impediments to further progress.

Keywords: biogas, upgrading, purification, utilization, SOFC, ethylene, reforming, siloxanes

\section{BIOGAS}

Efficient management of ever-increasing amounts of municipal, industrial and agricultural wastes in order to minimize their environmental impact is an urgent necessity. Biological treatment of wastes, which can be carried out either aerobically or anaerobically, is widely applied in this area. Due to their several advantages the anaerobic processes are to be preferred because they require considerably smaller installations, produce less sludge, operate at lower temperatures and are suited to periodic operation. Much more importantly, they generate biogas, which is an attractive potential source of renewable energy and/or added-value chemicals due to its high content of methane and $\mathrm{CO}_{2}$. Anaerobic digestion (AD) can proceed over a wide temperature range, from phychrophilic (ca. $10-20^{\circ} \mathrm{C}$ ) and mesophilic (ca. $20-45^{\circ} \mathrm{C}$ ) up to thermophilic (ca. $45-65^{\circ} \mathrm{C}$ ) and hyperthermophilic (ca. $\sim 70^{\circ} \mathrm{C}$ ) levels, by means of cooperation between anaerobes and facultative anaerobe microorganisms, which successively promote a sequence of hydrolysis-acidogenesis, 
acetogenesis and finally methanogenesis, that lead to biogas formation (Abatzoglou and Boivin, 2009; Weiland, 2010; Mao et al., 2015; Salihu and Alam, 2015). The quality of biogas, the digestion rate, the process stability, the richness in bacteria and the effectiveness in treating substrates containing lipids, proteins and nonbiodegradable solid matter, are parameters that are in principle influenced by both the pretreatment of the organic feedstocks and the $\mathrm{AD}$ operation temperature (Dareioti et al., 2009; Stamatelatou et al., 2010, 2012; Mao et al., 2015; Croce et al., 2016). Therefore, two-stage anaerobic digestion processes are often considered to be the optimal combination, namely thermophilic hydrolysis/acidogenesis and mesophilic methanogenesis.

Depending on the source of raw biomass and the particular treatment process, the biogas composition typically lies within the ranges $\mathrm{CH}_{4}=35-75 \%, \mathrm{CO}_{2}=25-65 \%, \mathrm{H}_{2}=1-5 \%, \mathrm{~N}_{2}=$ $0.3-3 \%$ (Table 1) along with traces of water vapor, $\mathrm{NH}_{3}, \mathrm{H}_{2} \mathrm{~S}$, and mercaptans (e.g., $\mathrm{CH}_{3} \mathrm{SH}$ ), halides and siloxanes (Abatzoglou and Boivin, 2009; Petersson and Wellinger, 2009). The amounts of these contaminants strongly depend on the biomass source and its treatment: they play a crucial role in determining biogas quality and its ultimate economic value, due to problems of fouling, corrosion and erosion when used in thermal or catalytic systems. Environmental pollution from hazardous secondary pollutants produced by the use of a raw biogas is another important issue. Accordingly, removal of contaminants is a necessary precursor to biogas utilization, and if it involves the removal of $\mathrm{CO}_{2}$ as well, the process is referred in the literature as biogas upgrading.

The most undesirable biogas impurities are $\mathrm{H}_{2} \mathrm{~S}$ and other $\mathrm{S}$ containing compounds with a typical concentration in the range $0.0001-1 \% \mathrm{vol}$, originating from the anaerobic fermentation of Sbearing proteins (Abatzoglou and Boivin, 2009). Although much research has been carried out to develop $\mathrm{H}_{2} \mathrm{~S}$-tolerant materials for the catalytic utilization of biogas, achieving $\mathrm{H}_{2} \mathrm{~S}$ reduction to the level of 10-100 ppmv remains a highly desirable goal.

Siloxanes, which are a case-sensitive biogas contaminant, are mostly found in gas originating from landfill and composting sites. Failure to remove siloxane impurities causes significant problems in both automotive engines and in catalytic/electrocatalytic systems due to the formation of silica microparticulates. It is therefore of crucial importance to remove siloxanes from biogas intended for energy or added-value chemical vectors.

Less harmful than $\mathrm{H}_{2} \mathrm{~S}$ and siloxanes, but also corrosive and a health risk, the $\mathrm{NH}_{3}$ present in biogas results from anaerobic fermentation of $\mathrm{N}$-containing organics. Ammonia itself is readily combusted or catalytically decomposed producing heat and/or electrical power in fuel cell applications of biogas. Therefore, it is not generally an important factor under operating conditionshowever $\mathrm{NH}_{3}$-derived $\mathrm{NOx}$ remains a potential pollutant that requires attention. The remaining contaminants in biogas may be considered of much lesser significance for most uses of biogas.

The thermal heating value of biogas varies between 15 and $30 \mathrm{MJ} / \mathrm{m}^{3}$, close to that of natural gas (Table 1 ); $1 \mathrm{~m}^{3}$ of biogas is equivalent to about $0.6 \mathrm{~L}$ of gasoline. It is often described as Renewable Natural Gas (RNG) or Substituted Natural Gas
(SNG) or even biomethane, since it is a pipeline-quality gas, which, after upgrading is fully equivalent to and interchangeable with natural gas so that it can partially substitute the latter in transport applications or grid injection. Accordingly, along with natural gas, biogas may be considered as a "bridge fuel" for the twentieth century, enabling the transition to a low-carbon energy economy, currently playing a key role in the emerging market for renewable energy. As a result, biogas purification and upgrading has been a prominent research topic in recent years. A number of comprehensive reviews are available including those provided by Abatzoglou and Boivin (2009), Ryckebosch et al. (2011), Sun et al. (2015); Andriani et al. (2014) and Salihu and Alam (2015). However, although biogas purification and upgrading has been extensively reviewed, its advanced utilization as a renewable energy vector and for the production of added-value chemicals has received much less attention. The latter aspect is the principal focus of the present review: after concisely reviewing state-of-theart purification and upgrading methods, in-depth consideration is given to the exploitation of biogas in the renewable energy and chemicals sectors. With respect to the former, particular emphasis is given to direct biogas solid oxide fuel cells which currently attract much research effort, although the information dispersed in the primary literature rather in reviews. Concerning the latter, the most promising potentially practical and environmentally benign utilization routes are reviewed here and an informative process sequence network is provided. Although some of the chemical routes are not new, they have not been previously considered for biogas utilization-for example transformation of biogas to ethylene via one-step process.

\section{BIOGAS PURIFICATION}

Biogas purification processes comprise mainly physical and chemical methods, but biological techniques capable of being effectively and economically applied even at small scales are also available (Abatzoglou and Boivin, 2009; Osorio and Torres, 2009; Salihu and Alam, 2015). Gas absorption, scrubbing or washing with specific liquid solvents, physical or chemical adsorption on high surface area solids, condensation (cryogenic separation), membrane separation, catalytic conversion, and biofiltration are the methods involved. Biogas upgrading is rapidly spreading all over the word; Petersson and Wellinger (2009) and Salihu and Alam (2015) provide information about current plant operations and distribution in a number of countries.

Here we focus on the principal contaminants that have to be removed in biogas purification processes, i.e., $\mathrm{H}_{2} \mathrm{~S}$ and siloxanes, and the main methodologies are summarized below.

\section{$\mathrm{H}_{2}$ S Removal}

$\mathrm{H}_{2} \mathrm{~S}$ removal via reactive-absorption techniques (passage of biogas through alkaline solutions- $\mathrm{NaOH}, \mathrm{CaO}$ ) is not a feasible method. This is because it is not a selective process; $\mathrm{CO}_{2}$ also reacts with alkaline solutions and would thus consume the costly alkalis. Moreover, as we shall see, $\mathrm{CO}_{2}$ is itself an economically valuable biogas component that can be used for cultivation of agricultural plants or for the production of added-value products by means of appropriate upgrading. 
TABLE 1 | Chemical composition of several origin biogases and natural gases.

\begin{tabular}{|c|c|c|c|c|c|c|c|c|c|}
\hline $\begin{array}{l}\text { Parameter, } \\
\text { component }\end{array}$ & Units & $\begin{array}{c}\text { Biogas from wastewater } \\
\text { A.D. plants }\end{array}$ & $\begin{array}{l}\text { Household } \\
\text { waste }^{b}\end{array}$ & $\begin{array}{l}\text { Agrifood industry } \\
\text { waste }^{\text {b }}\end{array}$ & $\begin{array}{l}\text { Agricultural } \\
\text { waste }^{b}\end{array}$ & $\begin{array}{l}\text { Landfill } \\
\text { sites }^{a, c}\end{array}$ & $\begin{array}{l}\text { Natural gas } \\
\text { (Danish) }^{c}\end{array}$ & $\begin{array}{l}\text { Natural gas } \\
\text { (Dutch) }^{\mathrm{c}}\end{array}$ & $\begin{array}{c}\text { Natural gas } \\
\text { (range comp.) }^{a}\end{array}$ \\
\hline $\mathrm{CH}_{4}$ & mol. \% & $60-70$ & $50-60$ & 68 & $60-75$ & $35-65$ & 89 & 81 & 85-92 \\
\hline $\mathrm{CO}_{2}$ & mol. \% & $30-40$ & $34-38$ & 26 & 19-33 & $15-50$ & 0.67 & 1 & $0.2-1.5$ \\
\hline $\mathrm{C}_{2+}$ hydroc & mol. \% & 0 & & - & - & 0 & 9.4 & 3.5 & 9 \\
\hline $\mathrm{H}_{2} \mathrm{~S}$ & ppm & $0-4000$ & $72-648$ & 288 & 2160-7200 & $0-100$ & 2.9 & - & $1.1-5.9$ \\
\hline $\mathrm{NH}_{3}$ & ppm & 100 & - & - & $72-144$ & $\sim 5$ & 0 & - & - \\
\hline $\mathrm{H}_{2}$ & mol. \% & 0 & - & - & - & $0-3$ & 0 & - & - \\
\hline $\mathrm{N}_{2}$ & mol. \% & 0.2 & $0-5$ & - & $0-1$ & $5-40$ & 0.28 & 14 & 0.3 \\
\hline $\mathrm{O}_{2}$ & mol. \% & 0 & $0-1$ & - & $<0.5$ & $0-5$ & 0 & 0 & - \\
\hline $\mathrm{H}_{2} \mathrm{O}$ & mol. \% (40 $\mathrm{C})$ & $1-5$ & $\leq 6$ & $\leq 6$ & $\leq 6$ & $1-5$ & - & - & - \\
\hline Total Cl & $\mathrm{mg} / \mathrm{m}^{3}$ & 100 & $100-800$ & - & - & 5 & - & - & - \\
\hline Aromatics & $\mathrm{mg} / \mathrm{m}^{3}$ & & $0-200$ & & - & & - & - & - \\
\hline Heating value (lower) & $\mathrm{MJ} / \mathrm{m}^{3}$ & 23 & & & - & 16 & 39.5 & 32 & 39 \\
\hline
\end{tabular}

a sun et al. (2015).

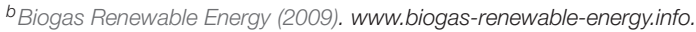

${ }^{c}$ Petersson and Wellinger (2009).

Various types of activated carbon have been investigated for $\mathrm{H}_{2} \mathrm{~S}$ removal mainly by adsorption/oxidation to produce elemental sulfur and to a lesser extent by conversion to $\mathrm{SO}_{2}$ (Bagreev and Bandosz, 2001; Bashkova et al., 2007; Xiao et al., 2008; Pipatmanomai et al., 2009; Kwansy and Balcerzak, 2016). Pore structure and surface characteristics as well as nitrogen content of the activated carbon affect both $\mathrm{H}_{2} \mathrm{~S}$ breakthrough capacity and selectivity toward elemental sulfur formation (Bashkova et al., 2007). On the other hand, Bagreev et al. (2001) concluded that the surface chemistry, specifically the surface acidity, of activated carbon seems to be the key factor that plays the dominant role in the $\mathrm{H}_{2} \mathrm{~S}$ breakthrough capacity, rather than surface area and pore volume characteristics. The relative humidity of the gas stream and alkali-impregnation were also found to be crucial to the performance of activated carbons used for $\mathrm{H}_{2} \mathrm{~S}$ removal (Xiao et al., 2008; Pipatmanomai et al., 2009). A reaction pathway for $\mathrm{H}_{2} \mathrm{~S}$ oxidation over activated carbon that involves the participation of all three vapor-liquid-solid phases has been proposed by Bagreev et al. (2001) and Xiao et al. (2008). The liquid phase consists of an extremely thin water film formed on the AC surface via water vapor condensation into which $\mathrm{H}_{2} \mathrm{~S}$ dissolves prior of its dissociation toward $\mathrm{H}^{+}$and $\mathrm{HS}^{-}$ions. Then a surface reaction occurs between $\mathrm{HS}^{-}$and dissociatively adsorbed oxygen $\left(\mathrm{O}_{\mathrm{ads}} *\right)$ on the activated carbon active sites $(*)$ forming elemental sulfur and water at the edge of the liquid film. Some of the $\mathrm{HS}^{-}$ions is are also oxidized to $\mathrm{H}_{2} \mathrm{SO}_{4}$. The net results is

$$
\mathrm{H}_{2} \mathrm{~S}+{ }^{1 / 2} \mathrm{O}_{2} \rightarrow \mathrm{S}+\mathrm{H}_{2} \mathrm{O} \text { and } \mathrm{H}_{2} \mathrm{~S}+2 \mathrm{O}_{2} \rightarrow \mathrm{H}_{2} \mathrm{SO}_{4}
$$

According to Bagreev et al. (2001) and Xiao et al. (2008) the steps involved are as follows, where $*$ is an active site on the AC surface.

$$
\mathrm{H}_{2} \mathrm{~S}(\mathrm{~g}) \rightarrow \mathrm{H}_{2} \mathrm{~S}_{\text {abs-liquid }}
$$

$$
\begin{aligned}
& \mathrm{H}_{2} \mathrm{~S}_{\mathrm{abs}-\text { liquid }} \rightarrow \mathrm{H}^{+}+\mathrm{HS}^{-} \\
& \left.\mathrm{O}_{2} \mathrm{~g}\right)+* \rightarrow \mathrm{O}_{\mathrm{ads}} * \\
& \mathrm{HS}^{-}+\mathrm{O}_{\mathrm{ads}} * \rightarrow \mathrm{S}_{\mathrm{ads}} *+\mathrm{OH}^{-} \\
& \mathrm{HS}^{-}+3 \mathrm{O}_{\text {ads }} * \rightarrow \mathrm{SO}_{2 \mathrm{ads}} *+\mathrm{OH}^{-} \\
& \mathrm{SO}_{2 \mathrm{ads}} *+3 \mathrm{O}_{\text {ads }} *+\mathrm{H}_{2} \mathrm{O} \rightarrow \mathrm{H}_{2} \mathrm{SO}_{4} \\
& \mathrm{H}^{+}+\mathrm{OH}^{-} \rightarrow \mathrm{H}_{2} \mathrm{O}
\end{aligned}
$$

The importance of water on the AC surface is clear from the above mechanism and explains why both relative humidity (RH) and the ability of the AC surfaces to adsorb water have a major influence on $\mathrm{H}_{2} \mathrm{~S}$ removal efficiency. Low $\mathrm{RH}$ values or hydrophobic AC surfaces indeed exhibit low $\mathrm{H}_{2} \mathrm{~S}$ removal efficiencies as shown by Xiao et al. (2008) who showed that impregnation of $\mathrm{AC}$ with $\mathrm{Na}_{2} \mathrm{CO}_{3}$ modifies the chemistry of the AC surface, enhancing water adsorption and promoting dissociation of $\mathrm{H}_{2} \mathrm{~S}$ and its subsequent removal.

Zeolite-based materials also possess high $\mathrm{H}_{2} \mathrm{~S}$ breakthrough capacities and therefore present an alternative strategy for $\mathrm{H}_{2} \mathrm{~S}$ removal (e.g., ion-exchanged zeolites, $\mathrm{CuO}$ or $\mathrm{ZnO}$-modified zeolites, etc.; Cosoli et al., 2008; Micoli et al., 2014), mesoporous silica (Belmabkhout et al., 2009) and iron oxide/hydroxide systems (so-called iron sponges) (Abatzoglou and Boivin, 2009). The basicity of these materials induces acid-base or redox reactions that result in efficient removal of $\mathrm{H}_{2} \mathrm{~S}$, for example:

$$
\begin{aligned}
& \text { Na-zeolite }+\mathrm{H}_{2} \mathrm{~S} \rightarrow \mathrm{H} \text {-zeolite }+ \text { NaHS } \\
& \mathrm{CuO}+\mathrm{H}_{2} \mathrm{~S} \rightarrow \mathrm{CuS}+\mathrm{H}_{2} \mathrm{O} \\
& \mathrm{Fe}_{2} \mathrm{O}_{3}+3 \mathrm{H}_{2} \mathrm{~S} \rightarrow \mathrm{Fe}_{2} \mathrm{~S}_{3}+3 \mathrm{H}_{2} \mathrm{O} \\
& 2 \mathrm{Fe}(\mathrm{OH})_{3}+3 \mathrm{H}_{2} \mathrm{~S} \rightarrow \mathrm{Fe}_{2} \mathrm{~S}_{3}+6 \mathrm{H}_{2} \mathrm{O}
\end{aligned}
$$

Iron sponge can also remove mercaptans

$$
\mathrm{Fe}_{2} \mathrm{O}_{3}+6 \mathrm{RSH} \rightarrow 2 \mathrm{Fe}(\mathrm{RS})_{3}+3 \mathrm{H}_{2} \mathrm{O}
$$


and are easily regenerated by $\mathrm{O}_{2}$

$$
\mathrm{Fe}_{2} \mathrm{~S}_{3}+3 / 2 \mathrm{O}_{2} \rightarrow \mathrm{Fe}_{2} \mathrm{O}_{3}+3 \mathrm{~S}
$$

Besides the above physical and chemical methods, biological processes are also widely employed for $\mathrm{H}_{2} \mathrm{~S}$ removal by microorganisms. These can achieve a satisfactory degree of desulfurization without the disadvantages associated with chemical processes. They can transform $\mathrm{H}_{2} \mathrm{~S}$ into $\mathrm{S}^{0}$ or $\mathrm{SO}_{4}^{2-}$ (depending on $\mathrm{O}_{2}$ availability) generating readily separated byproducts that could be used for other industrial processes. In addition, they require minimum nutrient input and display high robustness to temperature, $\mathrm{pH}$ and moisture fluctuations (Oyarzun et al., 2003; Syed et al., 2006; Abatzoglou and Boivin, 2009; Sun et al., 2015).

The most common biological technologies for $\mathrm{H}_{2} \mathrm{~S}$ removal include biofilters (i.e., Chung et al., 1996; Elias et al., 2002; Oyarzun et al., 2003), biotrickling filters (e.g., Kim and Deshusses, 2005; Fortuny et al., 2008; Rodriguez et al., 2014) and bioscrubbers (e.g., Sorokin et al., 2008; Van Den Bosch et al., 2008). These processes are effective and environmentally friendly for the removal of $\mathrm{H}_{2} \mathrm{~S}$, in particular at low concentrations of the latter (Fortuny et al., 2008; Tang et al., 2009). Moreover, most biological processes for $\mathrm{H}_{2} \mathrm{~S}$ removal use sulfideoxidizing bacteria (SOB), especially chemotropic species (mostly Thiobacillus sp., Thiotrix sp., Beggiato sp., Thermothrix sp.). A number of chemotrophic thiobacteria have been studied and found suitable for $\mathrm{H}_{2} \mathrm{~S}$ biodegradation and can be used in both aerobic conditions with $\mathrm{O}_{2}$ and anaerobic conditions (Syed et al., 2006; Abatzoglou and Boivin, 2009). Three patented $\mathrm{H}_{2} \mathrm{~S}$ purification processes, namely Thiopaq ${ }^{\circledR}$, Biopuric ${ }^{\circledR}$, and H2SPLUS SYSTEM ${ }^{\circledR}$, combining chemical scrubbers and bioreactors have been commercialized for large-scale biogas desulfurization (Fortuny et al., 2008; Sorokin et al., 2008; Abatzoglou and Boivin, 2009).

Chung et al. (2007), based on their previous findings of the behavior of the Thiobmillus thiopurus biofilter (Chung et al., 1996), demonstrating for the first time a two-stage biofilter for sequential treatment of concentrated $\mathrm{H}_{2} \mathrm{~S}$ and diluted $\mathrm{NH}_{3}$ mixtures. Their strategy of using a first biofilter of Thiobacillus thioparus for $\mathrm{H}_{2} \mathrm{~S}$ removal and a second biofilter of Nitrosomonas europaea for $\mathrm{NH}_{3}$ removal was very effective. Kobayashi et al. (2012) studied microbial mats for desulfurization of biogas in a full-scale anaerobic digester and characterized them in terms of their structure and chemical and microbial properties. Their results indicated that the key players in sulfide oxidation and sulfur production in the bio-desulfurization in the headspace of the digester were likely to be two sulfide-oxidizing bacteria species related to $H$. neapolitanus and $S$. denitrificans: the microbial community, cell density, bacterial activity varied depending on the environmental conditions. They also showed that the habitat of the SOB should be confined to the lower part of the headspace so as to improve operating conditions. Lohwacharin and Annachhatre (2010) investigated the successful operation of the biological sulfide oxidation process in an airlift biological reactor under oxygen-limited conditions and showed that up to $90 \%$ of sulfide removed was converted to elemental sulfur $\left(\mathrm{S}_{2} \mathrm{O}_{3}^{2-}\right.$ was the main by-product).

Fortuny et al. (2008) studied biotrickling filters with two different packing materials for the removal of ultra-high concentrations of $\mathrm{H}_{2} \mathrm{~S}$ from oxygen-poor gases as an interesting alternative for the treatment of off-gases containing high concentrations of $\mathrm{H}_{2} \mathrm{~S}$. They found that optimization of packing and operating conditions could improve the process. Similarly, Fernandez et al. (2013) tested a biotrickling filter packed with polypropylene Pall rings to remove $\mathrm{H}_{2} \mathrm{~S}$ from biogas under anoxic conditions and achieved $99 \%$ sulfur removal for $\mathrm{H}_{2} \mathrm{~S}$ inlet loads lower than $120 \mathrm{gSm}^{-3} \mathrm{~h}^{-1}$.

Ramos et al. (2014a,b) and Diaz et al. (2015) studied microaerobic conditions in order to control $\mathrm{H}_{2} \mathrm{~S}$ content and showed that the application of such conditions was an efficient method for $\mathrm{H}_{2} \mathrm{~S}$ control and removal from biogas. Moreover, Jeníček et al. (2017) confirmed the effectiveness of microaeration as a biochemical method of sulfide oxidation to elemental sulfur, obtaining $\mathrm{H}_{2} \mathrm{~S}$ removal efficiency more than $90 \%$ in most cases. An unusual approach is the combination of chemical and biological processes. Ho et al. (2013) proposed a chemicalbiological process to remove a high concentration of $\mathrm{H}_{2} \mathrm{~S}$ in biogas, in which $\mathrm{H}_{2} \mathrm{~S}$ was first oxidized by ferric iron to generate $S^{0}$ in a chemical reactor and the resulting ferrous iron was then oxidized in a biological reactor by iron-oxidizing bacteria. An $\mathrm{H}_{2} \mathrm{~S}$ removal efficiency of $98 \%$ was achieved indicating the feasibility of the method. Likewise, Lin et al. (2013) developed a pilot-scale chemical-biological $\mathrm{H}_{2} \mathrm{~S}$ removal process for biogas achieving $\mathrm{H}_{2} \mathrm{~S}$ removal efficiency up to $95 \%$, further highlighting the chemical-biological approach feasibility for biogas desulfurization.

\section{Siloxanes Removal}

Organic compounds that contain Si-C bonds, called organosilicons, are classified into organosilanes and organosiloxanes. The former are polymeric compounds containing Si-Si bonds with organic side-chains, the latter consist of a backbone of alternating Si-O units with organic side-chains attached to each $\mathrm{Si}$ atom (de Arespacochaga et al., 2015). Siloxanes have exceptional properties including thermal stability, low flammability, low surface tension and toxicity, hydrophobicity and high compressibility. They are therefore widely used in industry as additives in many products, including pharmaceuticals, detergents, cosmetics, shampoos, shaving foams, textiles, and coatings. Depending on the raw biomass used for biogas production, and in particular from landfill wastes and composts, the resulting biogas can contain significant amount of siloxanes, volatile methyl siloxanes (VMSs) being the most common species found in digester and landfill biogas. The most significant ones are listed in Table 2.

When siloxanes-containing biogases are used as an energy vector, silica microparticulates formed at high temperatures can create fouling and abrasion effects that are highly detrimental to the engine components of natural gas-fueled vehicles (Nair et al., 2012, 2013; Jalali et al., 2013; de Arespacochaga et al., 2015), to the anodic side of biogas-fueled solid oxide fuel cells (Haga et al., 2008; Madi et al., 2015) and to the catalysts used for 
TABLE 2 | Volatile Methyl Siloxanes commonly found in digester and landfill biogas ${ }^{a}$.

\begin{tabular}{|c|c|c|c|c|c|}
\hline Siloxane name & Abbreviation code & Chemical formula & M. weight (g/mol) & Boling point $\left({ }^{\circ} \mathrm{C}\right)$ & Water solubility (mg/L at $\left.25^{\circ} \mathrm{C}\right)$ \\
\hline Hexamethyldisiloxane & L2 & $\mathrm{C}_{6} \mathrm{H}_{18} \mathrm{OSi}_{2}$ & 162 & 107 & 0.93 \\
\hline Octamethyltrisiloxane & L3 & $\mathrm{C}_{8} \mathrm{H}_{24} \mathrm{O}_{2} \mathrm{Si}_{3}$ & 237 & 153 & 0.034 \\
\hline Decamethyltetrasiloxane & L4 & $\mathrm{C}_{10} \mathrm{H}_{30} \mathrm{O}_{3} \mathrm{Si}_{4}$ & 311 & 194 & 0.00674 \\
\hline Dodecamethylpentasiloxane & L5 & $\mathrm{C}_{12} \mathrm{H}_{36} \mathrm{O}_{4} \mathrm{Si}_{5}$ & 385 & 232 & 0.000309 \\
\hline Hexamethylcyclotetrasiloxane & D3 & $\mathrm{C}_{6} \mathrm{H}_{18} \mathrm{O}_{3} \mathrm{Si}_{3}$ & 223 & 135 & 1.56 \\
\hline Octamethylcyclotetrasiloxane & D4 & $\mathrm{C}_{8} \mathrm{H}_{24} \mathrm{O}_{4} \mathrm{Si}_{4}$ & 297 & 176 & 0.056 \\
\hline Decamethylcyclopentasiloxane & D5 & $\mathrm{C}_{10} \mathrm{H}_{30} \mathrm{O}_{5} \mathrm{Si}_{5}$ & 371 & 211 & 0.017 \\
\hline Dodecamethylcyclohexasiloxane & D6 & $\mathrm{C}_{12} \mathrm{H}_{36} \mathrm{O}_{6} \mathrm{Si}_{6}$ & 444 & 245 & 0.005 \\
\hline Trimethylsilanol & $\mathrm{TMOH}$ & $\mathrm{C}_{3} \mathrm{H}_{9} \mathrm{O}_{3} \mathrm{SiOH}$ & 90 & 99 & 42,600 \\
\hline
\end{tabular}

a Reproduced with permission of Elsevier from de Arespacochaga et al. (2015).

production of added-value chemicals from biogas. Accordingly, together with $\mathrm{H}_{2} \mathrm{~S}$, siloxanes are considered as one of the most undesirable contaminant in biogas (Dewil et al., 2006; Ohannessian et al., 2008; Jalali et al., 2013). It is therefore of importance to remove siloxanes from biogas at the first stages of upgrading and also before its use as RNG in energy generation or catalytic production of valuable chemicals. The subject is attracting increasing attention (Abatzoglou and Boivin, 2009; de Arespacochaga et al., 2015) and undergoing rapid development.

Several methods are effective for removal of siloxanes and may be considered as possible strategies for this purpose:

i. selective absorption in organic solvents,

ii. reactive absorption by active liquids (also called extraction or chemical abatement),

iii. adsorption on silica, molecular sieves, activated carbon or polymer particles,

iv. cryogenically.

To this end, Schweigkofler and Niessner (2001) showed that nitric acid and sulfuric acid are especially potent agents for siloxane removal (efficiencies $>95 \%$ ) at moderately elevated temperatures $\left(\mathrm{ca} .60^{\circ} \mathrm{C}\right.$ ) and in concentrated solutions, 65 and 97 wt\% respectively, whereas phosphoric acid was ineffective. Countercurrent absorption towers are necessary to ensure sufficient contact and therefore fast mass transfer between gas and liquid, although the high acidity involved is a significant techno-economic drawback for application of the method. The same authors have also researched siloxanes abatement via adsorption on a variety of solids. The adsorption capacity was found to depend strongly on the siloxane type (L2 and D5 siloxanes were tested), relative humidity of the biogas (the higher the humidity the lower the siloxane removal capacity), and of course on the nature of the adsorbent itself (activated charcoal, carbopack B, Tenax TA, XAD II resins, molecular sieve $13 \mathrm{X}$ and silica gel were tested). Activated charcoal and silica gel were found to be exceptionally effective sorbents and silica gel showed excellent thermal regeneration properties as well (ca. $250^{\circ} \mathrm{C}$ ).

Regenerable, activated alumina beds operated in continuous mode (double-bed, cyclic; alternately fused or trapping and regeneration) have been proposed for the efficient removal of siloxanes by Higgins (2007).
Montanari et al. (2010) studied D3 adsorption and adsorbent regeneration over three solids (silica gel, faujasite $\mathrm{NaX}$ zeolite and pure activated carbon) by means of FT-IR spectroscopy. Only partial regeneration was achieved with all these adsorbents in the temperature range of $20-200^{\circ} \mathrm{C}$ with either $\mathrm{N}_{2}$ flow or by applying vacuum. Hydrogen bonding to surface silanol groups is involved in the adsorption of D3 on silica, while with NaX zeolite molecular adsorption as well as chemical adsorption occurs. The authors discussed the advantages of choosing various types of activated carbon as preferred adsorbents for removal of D3 contamination from biogas.

Cabrera-Codony et al. (2014) investigated 12 commercial types of activated carbon as D4 siloxane adsorbents. They found a strong correlation between the textural properties of the ACs (in particular the total pore volume) and their D4 adsorption capacities, with a wood-based $\mathrm{H}_{3} \mathrm{PO}_{4}$-activated carbon offering the optimum adsorption capacity (D4 $\sim 1750$ $\mathrm{mg} / \mathrm{g}$ ) with dry $\mathrm{N}_{2}$ as carrier. This value was reduced by $>50 \%$ under typical biogas concentrations of D4 and in the presence of the major biogas components $\mathrm{CH}_{4}, \mathrm{CO}_{2}$ and water vapor. However, polymerization of siloxane on the adsorbent surface, promoted by oxygeated functional groups (phenolic and carboxylic) that occur on these wood-based types of AC, inhibits their thermal regeneration. The authors concluded that the activated carbons with high pore volume and low carboxylic and phenolic content may be very promising materials with both high siloxane capacities and good thermal regeneration characteristics.

Sigot et al. (2014) investigated the D4 adsorbing capacity of three materials: a coconut-based activated carbon $\left(930 \mathrm{~m}^{2} / \mathrm{g}\right.$ BET surface area), a $13 \mathrm{X}$ zeolite $\left(700 \mathrm{~m}^{2} / \mathrm{g}\right.$ BET surface area) and a Chameleon ${ }^{\circledR}$ silica gel $\left(690 \mathrm{~m}^{2} / \mathrm{g}\right.$ BET surface area). The silica gel exhibited the highest D4 adsorbing capacity: $\sim 250 \mathrm{mg} / \mathrm{g}$ at room temperature and $0 \%$ relative humidity $(\mathrm{RH})$. At a temperature $\sim 20^{\circ} \mathrm{C}$ higher, only a $15 \%$ decrease in capacity was found; however RH of the order of 70\% catastrophically decreased D4 adsorption at both temperatures. The surface chemistry of silica gel is dominated by siloxane $\mathrm{Si}-\mathrm{O}-\mathrm{Si}$ and silanol $\mathrm{Si}-\mathrm{O}-\mathrm{H}$ groups which show an affinity for compounds similar to D4: these are considered to play a key role in the superior capacity of silica gel compared to the other materials tested. 
Jiang et al. (2016) explored D4 siloxane adsorption over mesoporous aluminosilicate (UCT-15), a zeolite-type material developed at the University of Connecticut, which offers tuneable textural properties via variations in aluminum content and calcination ramp rate. The best D4 adsorption capacity (105 $\mathrm{mg} / \mathrm{g}$ ) was shown by UCT- 15 with $\mathrm{Si}: \mathrm{Al}=5$ and a $10^{\circ} \mathrm{C} / \mathrm{min}$ ramp rate, a value that is almost twice that of commercial ZSM-5, which has similar BET surface area and total pore volume. The as-prepared UCT-15 had a larger BET surface area, external surface area, mesopore volume and total pore volume. External surface area and mesopore volume were the key parameters governing the adsorption capacity. Hydroxyl groups on the surface of the aluminosilicates were found to promote the undesirable polymerization of D4, which is detrimental to adsorbent regeneration. In a more recent report Jafari et al. (2016) modified the textural properties of the mesoporous silica UCT-14, by tuning the temperature of gelation, calcination temperature and the heating rate to produce a material with high D4 adsorbing capacity (686 mg/g). This high value is comparable to that achieved with commercial silica gel under both dry and humid conditions. The modified UCT-14 (designated Si-Syn120) was more stable under consecutive use-regeneration cycles and somewhat more resistant to humidity in regard to performance deterioration, compared to commercial silica gel.

Cryogenic methods may also be considered for biogas purification from siloxanes. Although siloxanes can be fully removed $(>99 \%)$ at very low temperatures, ca. $-70^{\circ} \mathrm{C}$, Abatzoglou and Boivin (2009) pointed out the energy-intensive character of the method and the need for relevant technoeconomic analysis to demonstrate its sustainability.

Comprehensive reviews of biogas purification processes have been provided by Abatzoglou and Boivin (2009) and Ryckebosch et al. (2011).

\section{BIOGAS UPGRADING}

This term is typically used to describe processes that remove all impurities from biogas (i.e., desulfurization, siloxanes removal, drying, elimination of trace compounds) in addition to $\mathrm{CO}_{2}$ removal in order to achieve upgrading to natural gas with a high Wobbe Index $\left(\mathrm{M} / \mathrm{m}^{3}\right)$ as fuel for transport applications or grid injection, minimizing adverse effects associated with acid emissions (Abatzoglou and Boivin, 2009; Salihu and Alam, 2015). Upgrading strategies are mostly based on physical and/or chemical absorption in water or in active aqueous solutions (Cebula, 2009; Petersson and Wellinger, 2009; Kismurtono, 2011; Ryckebosch et al., 2011; Bansal et al., 2013; Khalil et al., 2014; Kohl and Nielsen, 1997) or adsorption on solid surfaces (Pandey and Fabian, 1989; Dabrowski, 2001; Jee et al., 2001; Yang, 2003; Himeno et al., 2005; Grande and Rodrigues, 2007; Ma et al., 2007; Cavenati et al., 2008; Das et al., 2008; Alonso-Vicario et al., 2010; Tippayawong and Thanompongchart, 2010; Grande, 2011, 2012; Yuan et al., 2013; Andriani et al., 2014), membrane separation methods (Wellinger and Lindberg, 2005; Favre et al., 2009; Petersson and Wellinger, 2009; Simons et al., 2009; Deng and Hagg, 2010; Makaruk et al., 2010; Ryckebosch et al., 2011; Andriani et al., 2014; Salihu and Alam, 2015), and biological methods (Ryckebosch et al., 2011; Andriani et al., 2014; Salihu and Alam, 2015) or even combinations of the above (Bansal et al., 2013).

On the other hand, the $\mathrm{CO}_{2}$ content of biogas may not be considered as an undesirable component; it is a raw material, which potentially could be used for enhanced oil recovery, and for augmenting the growth and production of algae and plants (as a carbon source for autotrophic microorganisms), and for the production of added-value chemicals, e.g., via hydrogenationsee below. Therefore, its regeneration during biogas upgrading is of substantial importance.

\section{Absorption Processes}

$\mathrm{CO}_{2}$ separation from a gas stream via absorption is a classical method, based either on physical or preferably on chemicallydriven absorption of $\mathrm{CO}_{2}$ in liquids or liquid solutions, taking place in bubble cap trays or in randomly packed towers (containing inert solid elements) where a countercurrent flow of gas mixture and liquid absorbent is applied; spray contactors of absorbent and gas mixture may also be possible in practical applications (Kohl and Nielsen, 1997). Countercurrent flow in randomly packed columns is well suited to absorption applications due to their more reliable design and generally superior performance. Based on the significantly higher solubility of $\mathrm{CO}_{2}$ in water compared to methane, particularly at lower temperatures (Figure 1), so-called water or physical scrubbing may be used for $\mathrm{CH}_{4}-\mathrm{CO}_{2}$ separation of biogas. The $\mathrm{CO}_{2}$-rich water leaving the absorption tower is regenerated by flashing followed by recycling. Biogas upgrading plants using water scrubbing with yield capacities of the order of $30-100 \mathrm{~m}^{3} / \mathrm{h}$ are in current use.

On the other hand, with the most effective chemically-based absorption of $\mathrm{CO}_{2}$ (often called chemical scrubbing), efficiencies up to $99.5 \%$ can be reached (Ryckebosch et al., 2011), with alkalis (e.g., $\mathrm{NaOH} ; \mathrm{Ca}(\mathrm{OH})_{2}$ ) or alkanolamines $\left(\mathrm{RNH}_{2} ; \mathrm{R}\right.$ is the organic component of the amine whose identity is not critical to the absorption reaction). Aqueous solutions of these bases

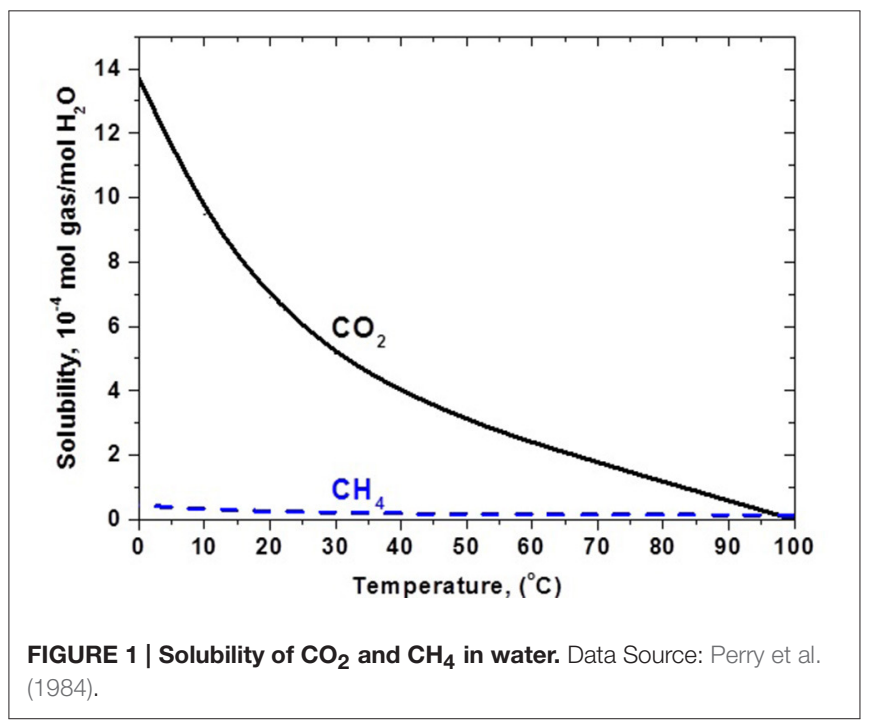


are generally used, where $\mathrm{CO}_{2}$ trapping occurs according to the following reactions:

$$
\begin{array}{r}
\mathrm{CO}_{2}+2 \mathrm{OH}^{-} \rightarrow \mathrm{CO}_{3}^{2-}+\mathrm{H}_{2} \mathrm{O} \stackrel{\mathrm{CO}_{2}}{\rightarrow} 2 \mathrm{HCO}_{3}^{-} \\
\text {(in alkaline solutions) } \\
\mathrm{CO}_{2}+\mathrm{RNH}_{2}+\mathrm{H}_{2} \mathrm{O} \rightarrow \mathrm{RNH}_{3}^{+}+\mathrm{HCO}_{3}^{-}
\end{array}
$$$$
\text { (in alkanolamine solutions) }
$$

The most common alkalolamines used include monoethanolamine (MEA), diethanolamine (DEA), triethanolamine (TEA), di-methylethanolamine (DMEA), methyldiethanolamine (MDEA), mixtures of glycol and monomethylamine, diglycolamine (DGA), diisopropanolamine (DIPA) and amine mixtures (Cebula, 2009; Petersson and Wellinger, 2009; Ryckebosch et al., 2011). After absorption, the consumed alkalolamine is regenerated by heating, and then recycled. During this process the following reaction takes place:

$$
\mathrm{RNH}_{3}^{+}+\mathrm{HCO}_{3}^{-} \rightarrow \mathrm{RNH}_{2}+\mathrm{H}_{2} \mathrm{O}+\mathrm{CO}_{2}
$$

It is possible for chemical scrubbing to be applied for the simultaneous removal of $\mathrm{CO}_{2}$ and $\mathrm{H}_{2} \mathrm{~S}$, in which case higher temperature is required for amine regeneration (Petersson and Wellinger, 2009). It is therefore preferable to remove $\mathrm{H}_{2} \mathrm{~S}$ from biogas before $\mathrm{CO}_{2}$ absorption as this is cheaper overall and generates clean $\mathrm{CO}_{2}$ for possible subsequent use.

\section{Adsorption Processes}

Adsorption, often referred to as chemisorption, the driving force behind heterogeneous catalytic reactions, is also widely applied for the selective separation of molecules from a fluid phase (Dabrowski, 2001). It is the spontaneous exothermic chemical reaction that occurs when a molecule (referred to as adsorbate), initially present in fluid phase, encounters the surface of an active solid (referred to as adsorbent). Adsorbents are porous solids with large surface areas per unit mass (typically $100-2,000 \mathrm{~m}^{2} / \mathrm{g}$ ), such as activated carbons, molecular carbon sieves, fullerenes, carbonaceous nanomaterials, silica gels, activated alumina and other metal oxides, metal hydroxides, zeolites, clay minerals and pillared clays, etc. They are effective for the selective adsorption of specific species from a fluid (gas or liquid) phase, thus removing them from the mixture. The adsorption isotherms of adsorbate species, often described by the Langmuir equilibrium equation, are of critical importance for the design of an adsorption-based separation process and enable determination of the solid surface capacity of the adsorbent for a specific adsorbed molecule. On the other hand, the kinetics and dynamics of adsorption, described by the more general term "adsorption dynamics," is affected by external, internal and surface diffusion characteristics of the adsorbed molecule, and, as described by Fick's second law, give the evolution with time of industrial adsorption processes used in separations (Kohl and Nielsen, 1997; Dabrowski, 2001).

Regeneration of the adsorbent, a key step in any separation process based on adsorption, can be performed by reducing the total pressure or by applying vacuum conditions on the saturated adsorbent: these processes are therefore termed pressure swing adsorption (PSA) or vacuum swing adsorption (VSA) respectively. Alternatively, regeneration may be achieved by increasing the temperature of the saturated adsorbent so as to desorb the adsorbate (temperature swing adsorption, (TSA)).

Adsoprtion-based removal of $\mathrm{CO}_{2}$ from biogas is widely practiced and commercially applied at both pilot and demonstration plant levels and is still an active research subject (Cavenati et al., 2008; Cebula, 2009; Petersson and Wellinger, 2009; Alonso-Vicario et al., 2010; Tippayawong and Thanompongchart, 2010; Grande, 2011; Montanari et al., 2010; Grande, 2012; Ryckebosch et al., 2011; Yuan et al., 2013; Andriani et al., 2014). The techniques used include PSA and TSA, both involving two packed-bed columns in a swing-type arrangement employing appropriate valve sequencing, as shown schematically in Figure 2. The operating principal is similar in the two cases, the main difference being the method used for adsorbent regeneration, i.e., either pressure or temperature variation. This two-column arrangement allows continuous-flow steady-state operation of the process, although the operation of individual columns is of course discontinuous and involves a multistep cycle. The simplest case uses a two-step cycle. One column is maintained at low temperature to continuously trap $\mathrm{CO}_{2}$ from the biogas flow (allowing free passage of $\mathrm{CH}_{4}$ through the packed bed) whilst the other is heated (TSA) or evacuated (PSA) to release previously adsorbed $\mathrm{CO}_{2}$. Note that the temperature

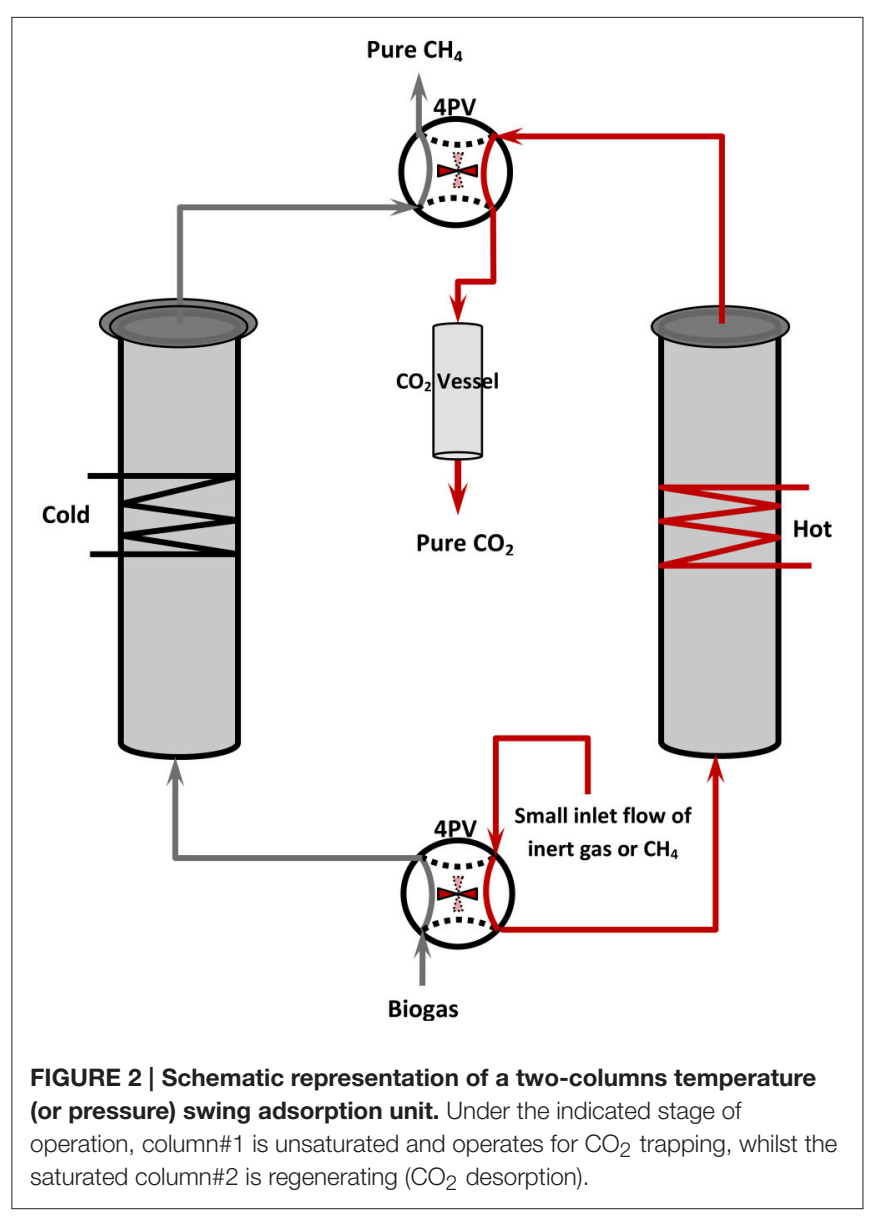


of the bed determines its adsorption capacity-the lower the temperature, the greater the adsorption capacity of an adsorbent for a given molecule. $\mathrm{A} \mathrm{CO}_{2}$ collection vessel is typically used, as well as a small portion of the purified methane stream (or an inert gas) in order to assist $\mathrm{CO}_{2}$ flow into the collection vessel and to purge the column, preparing it for the next cycle. In the second step, the two 4-port valves are synchronous turned to a second position such that the role of each column is reversed: the cleaned column \#2 now traps $\mathrm{CO}_{2}$, whilst the previously $\mathrm{CO}_{2}$ saturated column \#1 commences regeneration. The duration of the two-step cycle is a crucial design parameter that depends on the $\mathrm{CO}_{2}$ capacity of the columns. This must be appropriately determined in order to allow continuous utilization of the feedstream with continuous production of $\mathrm{CH}_{4}$ in the system's exhaust. The basic concept can be varied, especially in regard to the number of steps required for a complete cycle, and with respect to the operating sequence of the valves during each step (Grande, 2012). In addition to $\mathrm{CH}_{4}-\mathrm{CO}_{2}$ separation, the concept has been successfully applied in a number of other separations, for example in the purification of $\mathrm{H}_{2}$-containing streams for fuel cell applications (Nikolaidou et al., 2015); for $\mathrm{C}_{2} \mathrm{H}_{4}$ separation from $\mathrm{CH}_{4}$ and $\mathrm{O}_{2}$ in the oxidative coupling of methane, thus providing a one-step transformation of methane to ethylene with extremely high yields (Jiang et al., 1994); for air separation (Jee et al., 2001); for noble gas purification (Das et al., 2008); for n-paraffin/iso-paraffin separation (Yang, 2003), and others. The simplicity of PSA and its low capital and operational costs makes it very attractive in comparison to other fluid separation technologies.

Adsorbent characteristics are crucially important in adsorption-based biogas upgrading units. Their $\mathrm{CO}_{2}$ capacity and the temperatures required for sufficient $\mathrm{CO}_{2}$ adsorption and desorption are critical parameters that determine the economics and engineering aspects of the separation process. A wide variety of porous materials, including many kinds of zeolites, mesoporous materials, activated carbons and more recently high-surface area coordination polymers can be effectively applied in PSA and TSA. Yet other materials for this purpose are continuously under development, although only a few are used in current commercial PSA units. New research avenues are aimed at the simultaneous removal of $\mathrm{CO}_{2}$ and $\mathrm{H}_{2} \mathrm{~S}$ from biogas (Belmabkhout et al., 2009; Tippayawong and Thanompongchart, 2010). A significant cost-effectiveness parameter for potential adsorbents is their ease of regeneration, rather than their ultimate $\mathrm{CO}_{2}$-capacity. Accordingly, materials that exhibit quasi-linear $\mathrm{CO}_{2}$ adsorption isotherms at low pressures, as opposed to very steep ones that rapidly flatten above a certain pressure, are far preferable in PSA applications, even if the latter offer much higher ultimate capacities (Grande, 2012). Materials which meet the requirements for effective, low-cost $\mathrm{CH}_{4}-\mathrm{CO}_{2}$ separation are zeolites, carbon molecular sieves and activated carbons (Pandey and Fabian, 1989; Cebula, 2009; Montanari et al., 2010; Ryckebosch et al., 2011; Alonso-Vicario et al., 2010).

Compact PSA plants for $\mathrm{CH}_{4}-\mathrm{CO}_{2}$ separation with yields of the order of $250 \mathrm{~m}^{3} / \mathrm{h}$ have been already commercialized. They involve low capital and installation costs and are well suited to small scale applications. A comprehensive overview of the fundamentals of the PSA process and its evolution with time, with emphasis on $\mathrm{CH}_{4}-\mathrm{CO}_{2}$ separation, has recently been published by Grande (2012).

\section{Membrane Separation Processes}

The selective permeation of a molecule through a solid renders it as a potential membrane for the separation of that molecule from a gas mixture (Bernardo et al., 2009). Gas-gas and gasliquid membrane separation processes have been developed for practical applications (for example, in the latter case $\mathrm{CO}_{2}$ is extracted from a $\mathrm{CO}_{2}+\mathrm{CH}_{4}$ gas mixture into a liquid phase from which it is subsequently extracted by a second gas-liquid membrane thus achieving separation of the two components, Figure 3; Simons et al., 2009).

For biogas upgrading, membranes typically consist of materials that are permeable to $\mathrm{CO}_{2}$, water and $\mathrm{NH}_{3}$, partially permeable to $\mathrm{H}_{2} \mathrm{~S}$ and $\mathrm{O}_{2}$ and essentially non-permeable to $\mathrm{CH}_{4}$ and $\mathrm{N}_{2}$ (Favre et al., 2009; Petersson and Wellinger, 2009; Deng and Hagg, 2010; Makaruk et al., 2010; Ryckebosch et al., 2011; Andriani et al., 2014). However, water and $\mathrm{H}_{2} \mathrm{~S}$ are usually removed from biogas before $\mathrm{CO}_{2}$ separation as they can adversely affect membrane performance and efficiency. Due to the less than ideal efficiency of practical membranes, multi-stage separators are commonly used for efficient $\mathrm{CH}_{4}-\mathrm{CO}_{2}$ separation (Wellinger and Lindberg, 2005; Makaruk et al., 2010) and such biogas upgrading units with yield capacities $>200 \mathrm{~m}^{3} / \mathrm{h}$ are in current use.

\section{New Technologies}

Recent developments in biogas upgrading technology include cryogenic separation, in situ biological methane enrichment and the so-called ecological lung (Petersson and Wellinger, 2009; Ryckebosch et al., 2011; Kao et al., 2012). These methods, although promising and providing better performance than traditional well-established technologies already operating in micro-, meso-, and macro-scale biomethane production plants, are still under development. Both traditional and more recent biogas upgrading methods are being continuously improved and developed, so that the subject is a very active area of applied technology research. It is worth noting that all biogas upgrading technologies are capable of producing RNG for vehicle applications containing $>97 \% \mathrm{CH}_{4}$, which purity is superior to that of all globally produced natural gases. Ryckebosch et al. (2011) and Andriani et al. (2014) have reviewed biogas upgrading techniques currently in use or under development, providing comprehensive comparative technical and operational details, advantages/disadvantages, energy and technical requirements, maintenance and operational costs and other techno-economic information. More recently, Sun et al. (2015) published a comprehensive review covering biogas-upgrading technologies. As these authors point out, upgrading technology is site-specific, case-sensitive, and dependent on utilization requirements and local circumstances. They have critically evaluated state-of-theart purification and upgrading processes, providing much useful information in regard to product purity, methane recovery and loss, process efficiency, as well as the investment and operating costs of the various alternatives. 


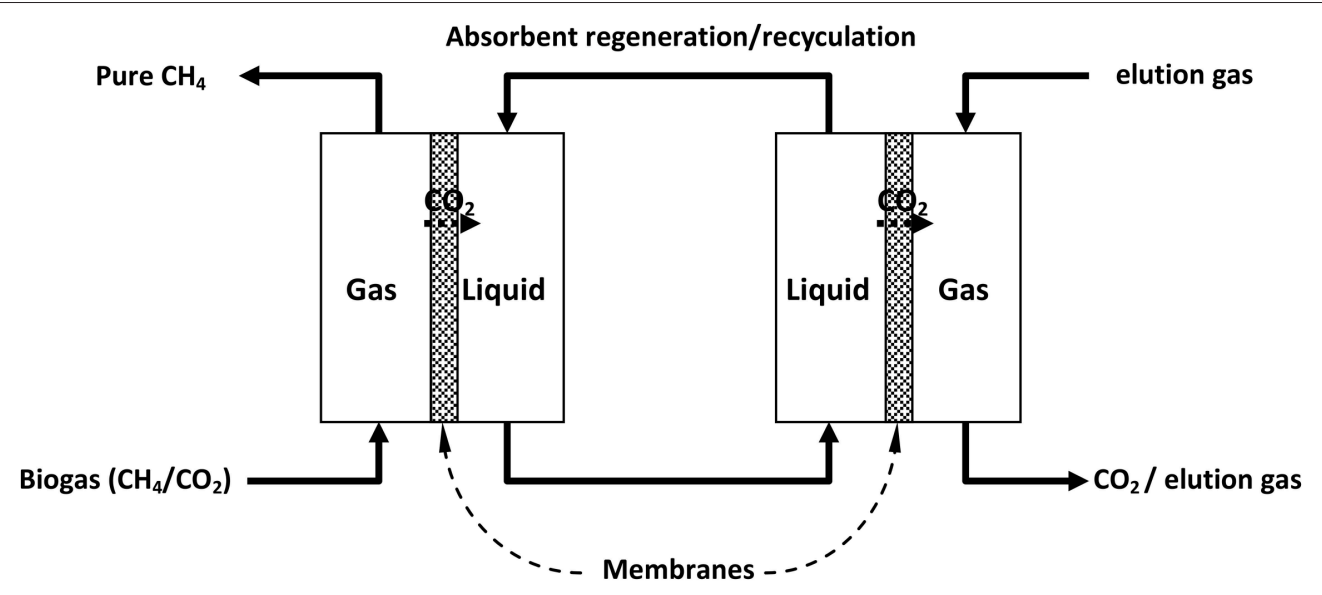

FIGURE 3 | Separation of $\mathbf{C H}_{\mathbf{4}}$ and $\mathbf{C O}_{2}$ in a combined double gas-liquid membrane process. [Reproduced with permission of Elsevier from Simons et al. (2009)].

\section{ADVANCED BIOGAS UTILIZATION}

This topic is the principal focus of the present review. Most biogas sources linked to anthropogenic activities (urban wastewater sludge, agricultural food industry sludge and animal farm manure anaerobic fermentation, landfill and commercial composting) yield gas that currently is used in specialized burners for heat production - a route for energy recovery that is not the most desirable one. Indeed, heat is a low quality form of energy that can be transformed to other high quality forms only with a very low efficiency. Even worse, low-grade biogas (i.e., minimal $\mathrm{CH}_{4}$ content) is inappropriate for direct heat production because at low methane levels the operation of biogas burners is inefficient. In such cases, large quantities of poor-quality biogases are instead wasted by highly detrimental venting to atmosphere, seriously contributing to environmental pollution. Biogas is widely available as a product of the decomposition of all living matter, it is therefore cheap and is a potential renewable carbon source for energy and chemicals production. Moreover, its usage addresses the imperative need for attaining sustainable development and eco-friendly production of energy and added-value chemicals. The increasing value of petroleum, combined with extensive use of fossil fuels and the associated greenhouse emissions have prompted researchers to focus on generating energy from low-carbon sources by means of ecofriendly modern technology. Biogas is a viable alternative to fossil fuels and its valorization is now a field of intense activity: research and development, technology and implementation are currently given high priority.

In this section, the major R\&D avenues for biogas valorization will be presented and discussed, regardless of their status of development, i.e., application, commercialization, pilot, demonstration or laboratory research. The presentation is based on the flow sheet shown in Figure 4, which depicts possible advanced routes for obtaining energy or added-value chemicals based on rational management and utilization of biogas.

The first step in Figure 4 concerns purification, i.e., removal of $\mathrm{H}_{2} \mathrm{~S}$, siloxanes, water vapor and other possible case-sensitive traces, in order to produce a pure $\mathrm{CH}_{4}-\mathrm{CO}_{2}$ mixture. Two alternative avenues may then be considered: avenue\#1, involves biogas external (route\#1-1) or internal (route\#1-2) reforming and also other more traditional methods (route\#1-3: combined heat and power engines, CHP, or route\# 1-4: heat production burners); the latter lie outside the scope of this review. Avenue\#2 concerns upgrading of the purified biogas, i.e., separation of $\mathrm{CH}_{4}$ and $\mathrm{CO}_{2}$.

Methane (external) reforming (route\#1-1, Figure 4) is a well-established technology for synthesis gas $\left(\mathrm{H}_{2}+\mathrm{CO}\right)$ or $\mathrm{H}_{2}$ production (e.g., Ashcroft et al., 1991; Bradford and Vannice, 1999; Verykios, 2003; Papadopoulou et al., 2012; Yentekakis et al., 2015). Practically, any composition (poor, equimolar, or rich in $\mathrm{CH}_{4}$ ) of the purified biogas itself is a suitable feed for the dry reforming of methane (DRM) process, which occurs through the reaction ( $\mathrm{R} 18)$ :

$$
\mathrm{CH}_{4}+\mathrm{CO}_{2} \rightarrow 2 \mathrm{CO}+2 \mathrm{H}_{2}
$$

producing $\mathrm{H}_{2}$ and $\mathrm{CO}$, so-called syngas, since it can be fed to Fischer-Tropsch synthesis technology (path\#1-1-1, Figure 4) to produce liquid energy carriers (e.g., Schulz, 1999; Selvatico et al., 2016). This probably represents one of the most attractive routes for biogas valorization as a renewable carbon source.

Dry reforming of methane has been investigated over a variety of metal catalysts (e.g., Ni, Pt, Rh, Ir, Ru, Pd, Co) supported on oxide or mixed oxide supports (e.g. $\mathrm{Al}_{2} \mathrm{O}_{3}, \mathrm{La}_{2} \mathrm{O}_{3}, \mathrm{CeO}_{2}, \mathrm{SiO}_{2}$, $\mathrm{TiO}_{2}, \mathrm{La}_{2} \mathrm{O}_{3}-\mathrm{SiO}_{2}, \mathrm{ZrO}_{2}-\mathrm{SiO}_{2}, \mathrm{PrO}_{2}-\mathrm{Al}_{2} \mathrm{O}_{3}$ ). Most of these catalysts are very active for the DRM reaction. A major problem that concerns especially nickel-based catalysts (the cheapest) is coke deposition, which eventually results in catalyst deactivation; some very recent studies are focused on Ni-based bimetallic catalysts which exhibit reduced carbon deposition (Niakolas et al., 2015). This drawback does not affect noble metal catalysts which show similar activity but are very resistant to carbon deposition, and hence attractive candidates for use in practical applications of DRM. Recently, it was shown that Ir is an extremely stable catalyst at high temperatures under oxidative 


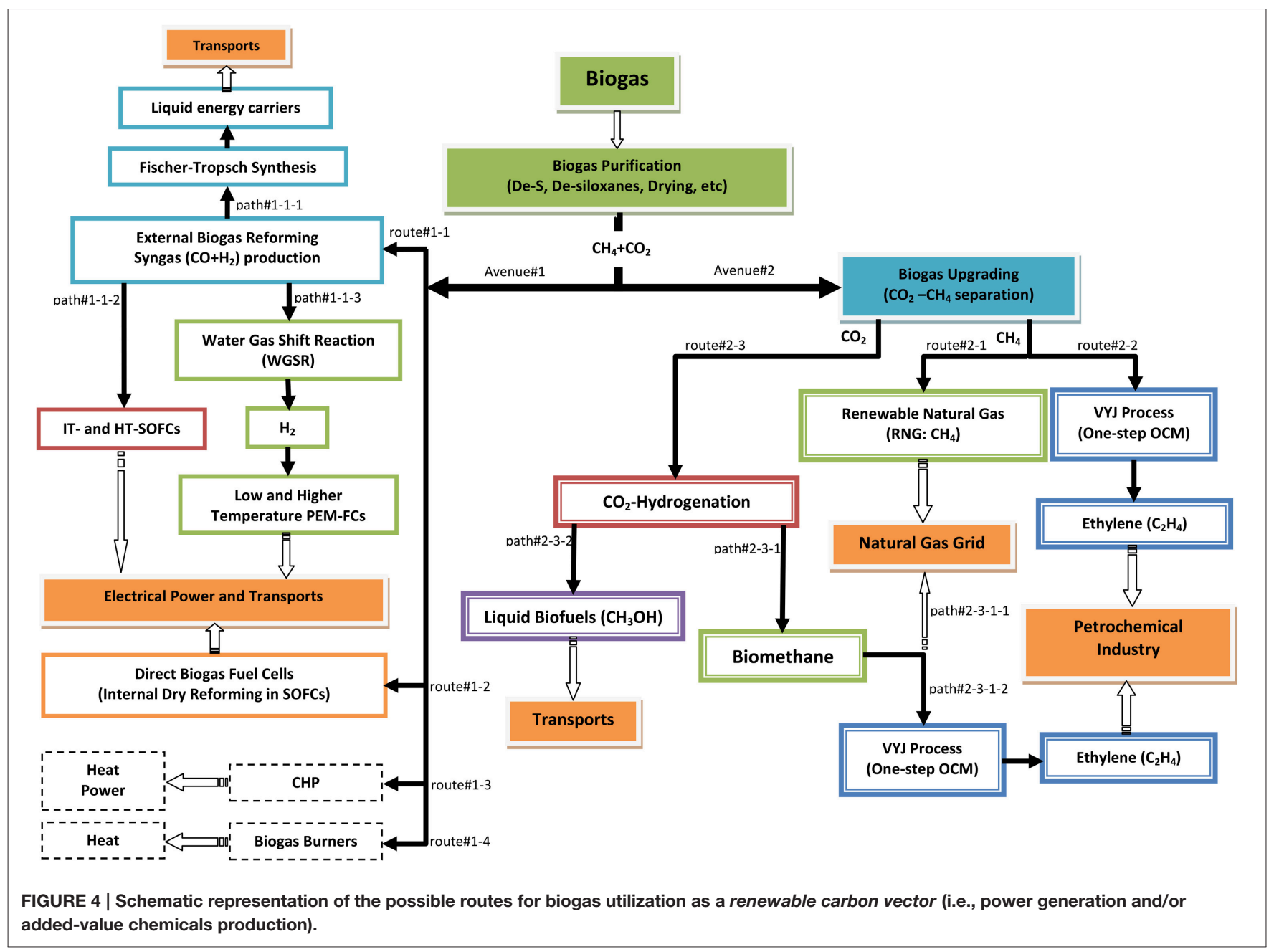

conditions; it therefore fulfills all the necessary requirements for practical DRM applications (Yentekakis et al., 2015).

It is beyond the scope of the present review to consider DRM in any detail. It has been well studied for many years and several comprehensive reviews are available (e.g., Rostrup-Nielsen and Hansen, 1993; Bradford and Vannice, 1999; Verykios, 2003).

As an alternative to the Fischer-Tropsch synthesis route, syngas $\left(\mathrm{CO}+\mathrm{H}_{2}\right)$ can be utilized as an efficient fuel in high temperature solid oxide fuel cells for electrical power generation (path\#1-1-2, Figure 4), although the aforementioned internal reforming process offers some engineering and economic advantages as schematically shown in Figure $\mathbf{5}$.

A further alternative is the use of syngas for $\mathrm{H}_{2}$ production via the water-gas-shift reaction (R19) which converts $\mathrm{CO}$ to $\mathrm{CO}_{2}$ and simultaneously enriches the $\mathrm{H}_{2}$ content of the effluent gas (path\#1-1-3):

$$
\mathrm{CO}+\mathrm{H}_{2} \mathrm{O} \leftrightarrow \mathrm{CO}_{2}+\mathrm{H}_{2}
$$

After $\mathrm{CO}_{2}$ removal, the product (pure $\mathrm{H}_{2}$ with very low levels of $\mathrm{CO}$ ) can either be used for electrical power generation in polymeric membrane low temperature $\left(\sim 80^{\circ} \mathrm{C}\right)$ fuel cells (PEMFCs) or can be stored for fueling zero emission vehicles. It is well known, however, that low temperature PEM-FCs are very sensitive to $\mathrm{CO}$ impurities in the $\mathrm{H}_{2}$ fuel. The technology for rigorous $\mathrm{CO}$ removal $(<20 \mathrm{ppm})$ has been developed, is commercially available, and has been applied in micro- and meso-scale units (Helbio). It is also worth noting that high performance polymer electrolytes for PEM fuel cells have been discovered by Neophytides, Kallitsis and coworkers (Geormezi et al., 2011, 2012). These operate at $150-200^{\circ} \mathrm{C}$ and are insensitive to $\mathrm{CO}$ impurities (up to $\sim 1 \%$ ). This avenue for biogas utilization has been successfully applied (Nikolaidou et al., 2015) in a demonstration (pilot) scale process in which, starting from winewaste sludge, an $\sim 500 \mathrm{~W}$ electrical power pilot unit with a stack of 17 elevated temperature $\left(180^{\circ} \mathrm{C}\right)$ PEM unit cells was successfully constructed and tested.

As shown in Figure 4, an alternative route for biogas utilization is its use in intermediate- or high-temperature fuel cells that use internal reforming for renewable energy production (route\#1-2, Figure 4). This concept, also called direct-biogas solid oxide fuel cell (DB-SOFC), offers several advantages in comparison to the previously discussed method of external reforming (Figure 5), has currently received much attention in both experimental (Goula et al., 2006; Yentekakis, 2006; Shiratori et al., 2008, 2010; Yentekakis et al., 2008; Lanzini and Leone, 2010; 

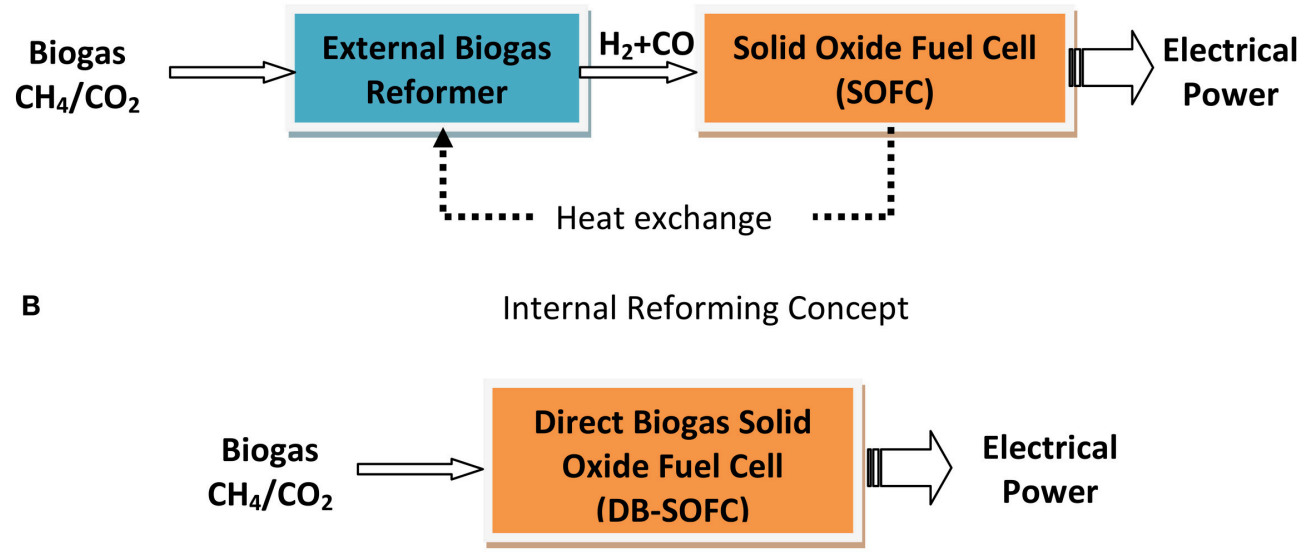

FIGURE 5 | Schematic of the differences between external (A) and internal (B) reforming concepts for SOFC-added electrical power generation from biogas.

Papadam et al., 2012; Takahashi et al., 2012; Lanzini et al., 2013; Ma et al., 2015; and references therein) and modeling studies (Lanzini et al., 2011; Ni, 2013; Janardhanan, 2015a,b). Most of these studies made use of Ni-based cermet anodes, doped with additives in some cases in order to prevent carbon deposition (e.g., Yentekakis, 2006; Ma et al., 2015; Niakolas et al., 2015). Table 3 summarizes some direct biogas fuel cells studies that are worthy of particular note.

The main findings of these works were as follows:

i. Internal dry reforming of $\mathrm{CH}_{4}$ in solid oxide fuel cells is possible even with traditional inexpensive Ni-based cermet anode, without deterioration of cell performance during operation (Goula et al., 2006; Papadam et al., 2012), independently of the biogas quality (low to high $\mathrm{CH}_{4}$ biogas content). This is because the current flux through the cell prevents carbon accumulation on the anode via the reactions:

$$
\begin{gathered}
\mathrm{C}+\mathrm{O}^{2-} \rightarrow \mathrm{CO}+2 \mathrm{e}^{-} \\
\mathrm{C}+2 \mathrm{O}^{2-} \rightarrow \mathrm{CO}_{2}+4 \mathrm{e}^{-}
\end{gathered}
$$

These charge transfer reactions occur in parallel with the principal electro-productive reactions between $\mathrm{O}^{2-}$ and the reformates $\left(\mathrm{H}_{2}, \mathrm{CO}\right)$, also taking place on the anode, i.e.,

$$
\begin{aligned}
& \mathrm{H}_{2}+\mathrm{O}^{2-} \rightarrow \mathrm{H}_{2} \mathrm{O}+2 \mathrm{e}^{-} \\
& \mathrm{CO}+\mathrm{O}^{2-} \rightarrow \mathrm{CO}_{2}+2 \mathrm{e}^{-}
\end{aligned}
$$

further contributing to the cell's electrical power generation (Goula et al., 2006; Papadam et al., 2012). Recall that the reactions responsible for carbon deposition on the anodes of direct hydrocarbon fuel cells are the methane pyrolysis reaction (R24) and Boudouard reaction (R25)

$$
\begin{aligned}
\mathrm{CH}_{4} & \rightarrow \mathrm{C}+2 \mathrm{H}_{2} \\
2 \mathrm{CO} & \rightarrow \mathrm{C}+\mathrm{CO}_{2}
\end{aligned}
$$

which together with the reforming reaction (R18) and the water gas shift (WGS) reaction (R19)

$$
\mathrm{CO}+\mathrm{H}_{2} \mathrm{O} \leftrightarrow \mathrm{CO}_{2}+\mathrm{H}_{2}
$$

are the principal chemical and electrochemical reactions taking place in an internal methane reforming fuel cell (Wang et al., 2013; Gur, 2016).

ii. Although the best cell output characteristics (power density) are obtained at around equimolar biogas composition $\left(\mathrm{CH}_{4} / \mathrm{CO}_{2} \sim 1\right)$, it is also the case that even poor (low $\mathrm{CH}_{4}$ content) biogas is suitable feed for stable and productive fuel cell operation (Yentekakis et al., 2008; Guerra et al., 2013, 2014).

iii. Both intermediate $\left(600-800^{\circ} \mathrm{C}\right)$ and high temperature $(800-$ $1,000^{\circ} \mathrm{C}$ ) fuel cells operate successfully under direct biogas feed (Yentekakis, 2006; Yentekakis et al., 2008; Papadam et al., 2012). In regard to this, fast $\mathrm{O}^{2-}$-ionic conduction in the solid electrolyte at the required cell operating temperature is the key factor-rather than the kinetics of the anodic chemical and electrochemical reactions; the latter appear to be fast at temperatures $>\sim 600^{\circ} \mathrm{C}$.

iv. Electrical power output characteristics of direct biogas FCs were found to compare favorably with those obtained with the same cell under $\mathrm{H}_{2}$ feed (Fuerte et al., 2014; Ma et al., 2015). This probably implies that reaction (R22) dominates cell performance. Promotion of reaction (R23) is expected to enhance cell performance, as shown by theoretical studies (Ni, 2013). This can be achieved by developing selective electrocatalysts for reaction (R23).

$\mathrm{v}$. Early studies mainly focused on the feasibility of the process with respect to the anodic electrocatalysts employed, which showed the appropriateness of Ni-based composites as active and durable anodic materials. Recent trends also involve optimization of fuel cell compartments and characteristics, aimed at minimizing ohmic overpotential of the cell (found to be the main source of cell polarization) so as 


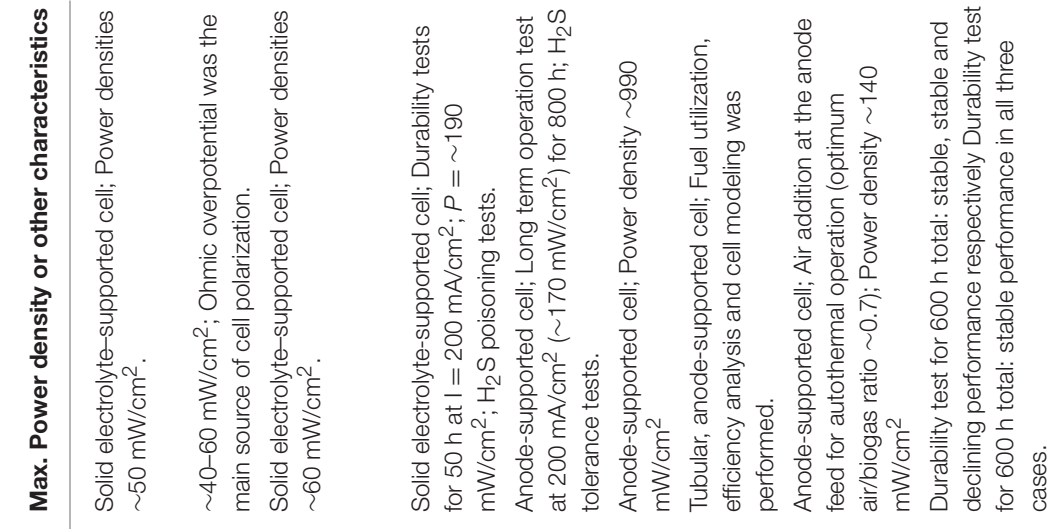

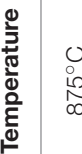
$\begin{array}{lll} & 0 \\ 0 & 8 \\ 0 & 9 \\ 0 & 9 \\ 0 & 8 \\ 0 & 8 \\ & & 8\end{array}$

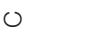

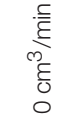

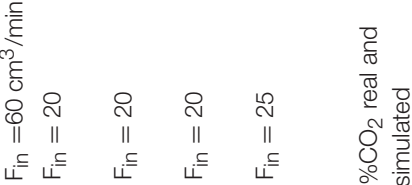

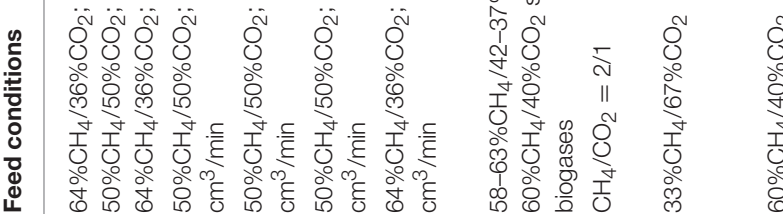

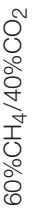
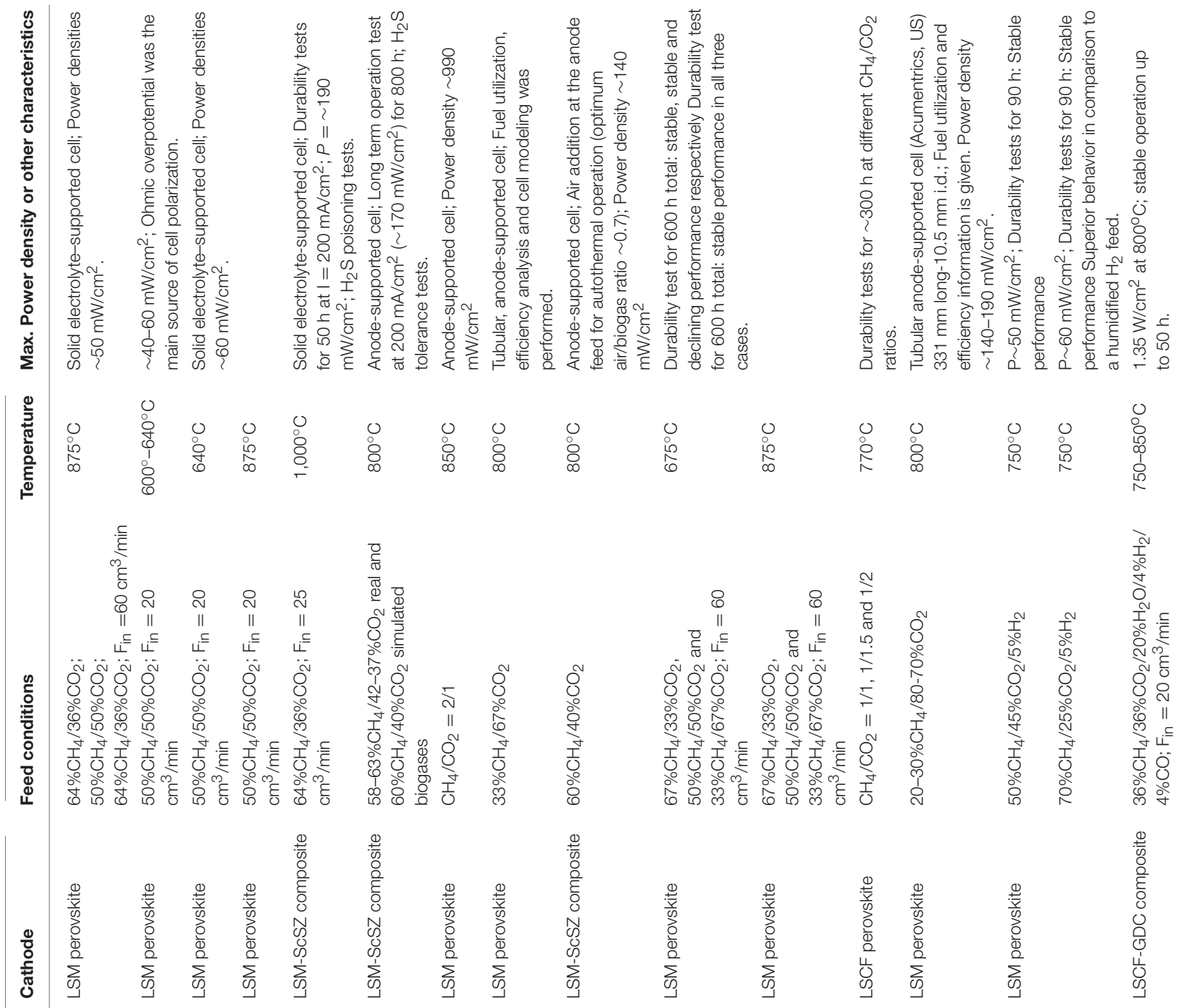

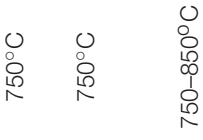

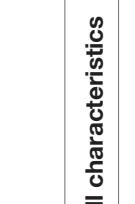

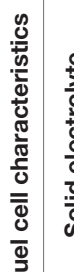

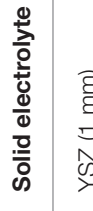

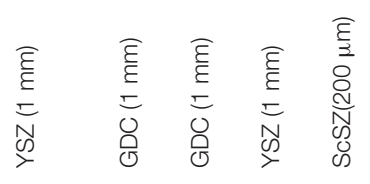

$\bar{\varepsilon}$
$\overline{2}$
$\frac{0}{N}$
0
0
$\infty$

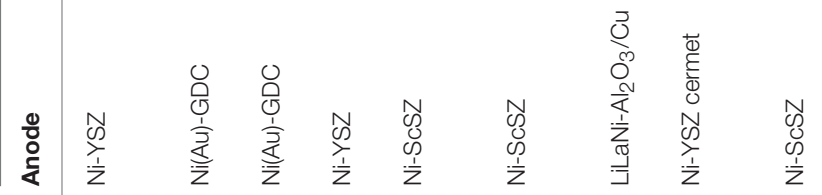

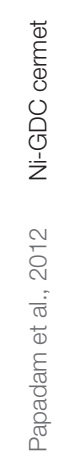

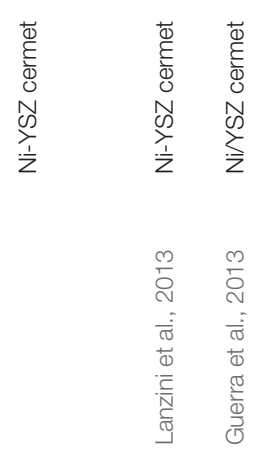
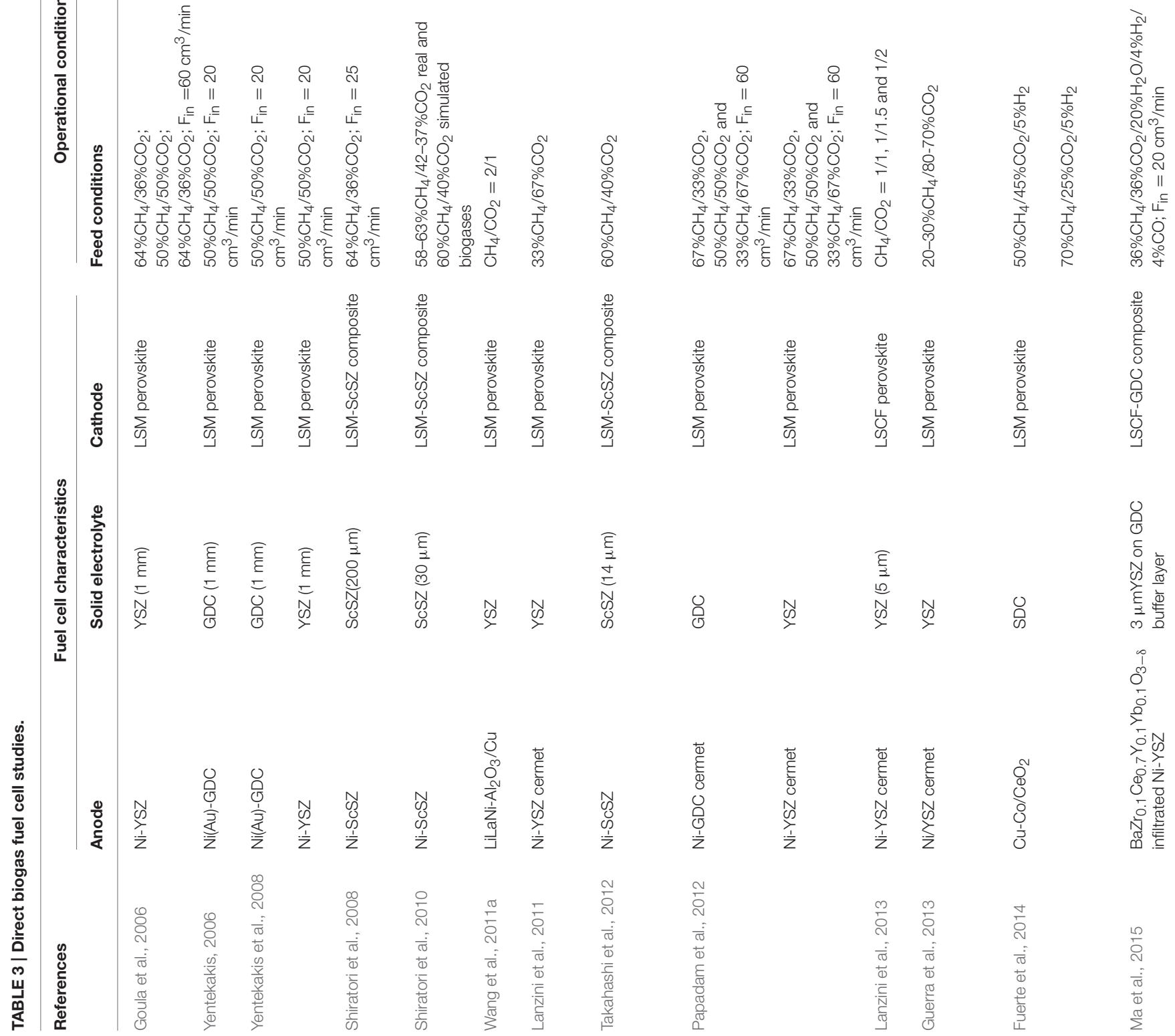

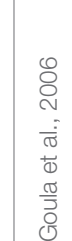

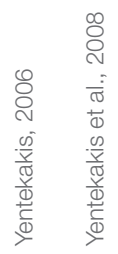

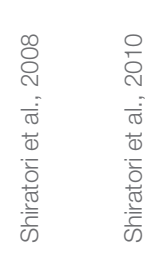

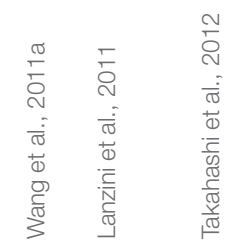

응

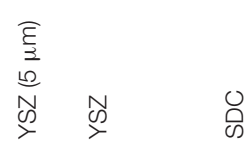

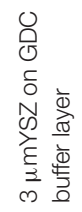

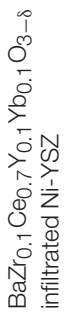


to increase power output and efficiency. With this aim, anode- or cathode-supported fuel cell designs with very thin solid electrolytes (ca. 3-20 $\mu \mathrm{m}$ ) were successfully applied, delivering as expected superior power generation (Wang et al., 2011a; Takahashi et al., 2012; Ma et al., 2015). Further development of anodic materials together with advanced fuel cell designs that minimize cell overpotentials (of which there is much expertise in solid oxide fuel cell technology) in combination with optimal operational conditions (information provided by direct biogas fuel cell modeling studies) are expected to lead to the development of highly efficient and cost-effective direct biogas fuel cells in the near future.

The second basic avenue\#2 of Figure 4 is now considered. It concerns biogas upgrading after purification. Upgrading leads into two separated products: pure $\mathrm{CH}_{4}$ and pure $\mathrm{CO}_{2}$. The former can be directly supplied to the national natural gas grid for transport use, as RNG or as a substitute natural gas (SNG), so-called biomethane (route\#2-1). An alternative and more attractive route to biomethane valorization (route \#22) would be its utilization for ethylene $\left(\mathrm{C}_{2} \mathrm{H}_{4}\right)$ production, as proposed by Vayenas, Yentekakis and Jiang (VYJ process) (Jiang et al., 1994; Vayenas et al., 1995; Yentekakis et al., 1995, 1996; Makri et al., 1996) by means of the one-step oxidative coupling of methane (OCM) reaction (Keller and Bhasin, 1982; Ito and Lunsford, 1985; Lunsford, 1990):

$$
\mathrm{CH}_{4} \stackrel{+\mathrm{O}_{2}}{\longrightarrow} \mathrm{C}_{2} \mathrm{H}_{2}+\mathrm{C}_{2} \mathrm{H}_{4}+\mathrm{C}_{2} \mathrm{H}_{6}+\mathrm{H}_{2} \mathrm{O}
$$

The VYJ process is an one-step method for oxidatively coupling methane to ethylene with yields up to $85 \%$ and total $\mathrm{C}_{2}$ hydrocarbons $\left(\mathrm{C}_{2} \mathrm{H}_{4}\right.$ and $\left.\mathrm{C}_{2} \mathrm{H}_{6}\right)$ up to $88 \%$ (Jiang et al., 1994). Such performance is achievable in a gas recycle electrocatalytic or catalytic reactor-separator where the recycled gas continuously passes through a molecular sieve trap in the recycle loop. The outputs of this process are ethylene selectivity up to $88 \%$ at methane conversion up to $97 \%$, with a $\mathrm{C}_{2} \mathrm{H}_{4}$ yield of the order of $85 \%$ (Jiang et al., 1994). These values are economically very attractive for development on an industrial scale of this one-step method for production of ethylene from biogas. Ethylene is one of the most important raw materials of the petrochemical industry, used for the production of a wide range of added-value chemicals and plastics (Austin, 1984). For a country with well-established petrochemical industry, such utilization of biogas would represent the most attractive way of its valorization (Chemistry and industry, 1994) and should be considered a high priority.

In regard to the $\mathrm{CO}_{2}$ product from the upgrading unit (see Figure 4), the following pathways may be proposed. $\mathrm{A} \mathrm{CO}_{2}$ reduction (hydrogenation) process (route\#2-3; paths \#2-3-1 and \#2-3-2), transforming $\mathrm{CO}_{2}$ to $\mathrm{CH}_{4}$ through the so-called Sabatier reaction (R27) or to methanol (R28),

$$
\begin{array}{rr}
\mathrm{CO}_{2}+4 \mathrm{H}_{2} \rightarrow \mathrm{CH}_{4}+2 \mathrm{H}_{2} \mathrm{O} & \Delta \mathrm{H}^{\circ}=-165 \mathrm{~kJ} / \mathrm{mol} \\
& (\mathrm{R} 27) \\
\mathrm{CO}_{2}+3 \mathrm{H}_{2} \rightarrow \mathrm{CH}_{3} \mathrm{OH}+\mathrm{H}_{2} \mathrm{O} & \Delta \mathrm{H}^{\circ}=-53.3 \mathrm{~kJ} / \mathrm{mol}
\end{array}
$$

including the formation of other carbonaceous products, such as $\mathrm{CO}$, higher hydrocarbons, dimethyl ether, higher alcohols or formic species (Wang et al., 2011b; Jadhav et al., 2014; Saeidi et al., 2014; Puga, 2016). $\mathrm{Ru}$ is an active catalysts for $\mathrm{CO}_{2}$ methanation, followed by Ni, Fe and Co (Wang et al., 2011b; Puga, 2016), while for formation of methanol and formaldehyde, $\mathrm{Cu}, \mathrm{Cu}-\mathrm{Zn}$ and $\mathrm{Ni}$-Co based supported catalysts are effective (Wang et al., 2011b; Jadhav et al., 2014). There are however both chemical and engineering problems to be solved in regard to these reactions. Both (R27) and (R28) are exothermic and involve a reduction in volume and are therefore thermodynamically favored at low temperatures and elevated pressures. But low temperatures decrease reaction rates, whereas typical catalytic systems are active at moderate temperatures ca. $200-400^{\circ} \mathrm{C}$ (Wang et al., 2011b; Saeidi et al., 2014; Puga, 2016). The goal therefore is to develop catalysts that are sufficiently active and selective at low temperatures and, if possible, at atmospheric pressure. This is currently a priority research area where surface- or support-induced promotion of the active phases nano-structured catalyst architectures can play a key role. For example, $\mathrm{TiO}_{2-}$ supported $\mathrm{Ru}$ nanoparticles are a very promising catalysts for $\mathrm{CO}_{2}$ methanation (Abe et al., 2009).

$\mathrm{CO}_{2}$ reduction may also be achieved photochemically and/or electrochemically either with $\mathrm{H}_{2}$ or with $\mathrm{H}_{2} \mathrm{O}$ (Roy et al., 2010; Hoffmann et al., 2011; Habisreutinger et al., 2013; Ganesh, 2014; Jadhav et al., 2014; Puga, 2016). The photochemical reduction is also called "energy-to-power" (P2G) technology or even "artificial photosynthesis" in which $\mathrm{H}_{2}$ produced via a solardriven water splitting system by means of electrolysis can drive $\mathrm{CO}_{2}$ hydrogenation to yield biomethane or liquid biofuels.

Nowadays, conversion of $\mathrm{CO}_{2}$ into value added chemicals, especially using photocatalysis, is an important world-wide research priority. Progress, challenges and perspectives have been documented in a number of comprehensive reviews, such as those by Wang et al. (2011b), Ganesh (2014), Roy et al. (2010), Saeidi et al. (2014), Hoffmann et al. (2011).

Returning to Figure 4, following the path\#2-3-1, biomethane may be fed into the natural gas grid (path\#2-3-1-1) or further upgraded to be transformed to ethylene (path\#2-3-1-2) by means of Vayenas-Yentekakis-Jiang (VYJ) process (Vayenas et al., 1995), similar to route\#2-2. In other words, should it be desired, it is possible to transform all the carbon content of biogas to ethylene by means of combining path\#2-3-1-2 and route\#2-2 (Figure 4). This scenario would transform wastewater treatment plants and other biogas-producing sites into small-scale ethylene production units.

A synopsis of the above analysis of biogas management as a renewable carbon source in terms of the final product is given below in Table 4. Note that the possible advanced alternative uses that could be applied in practice are subject to the amount of available biogas and to local, regional or global (national) ecoor economic targets.

The significance in respect to the above discussion is that all the necessary technology for complete valorization of biogas (both $\mathrm{CH}_{4}$ and $\mathrm{CO}_{2}$ content) is currently available and/or rapidly developing. This accounts for the major R\&D and technology interest in biogas valorization, since it represents a unique, widely available and cheap renewable carbon source, providing the 
TABLE 4 | Synopsis of specific process sequences leading to specific desired products from a biogas feedstock.

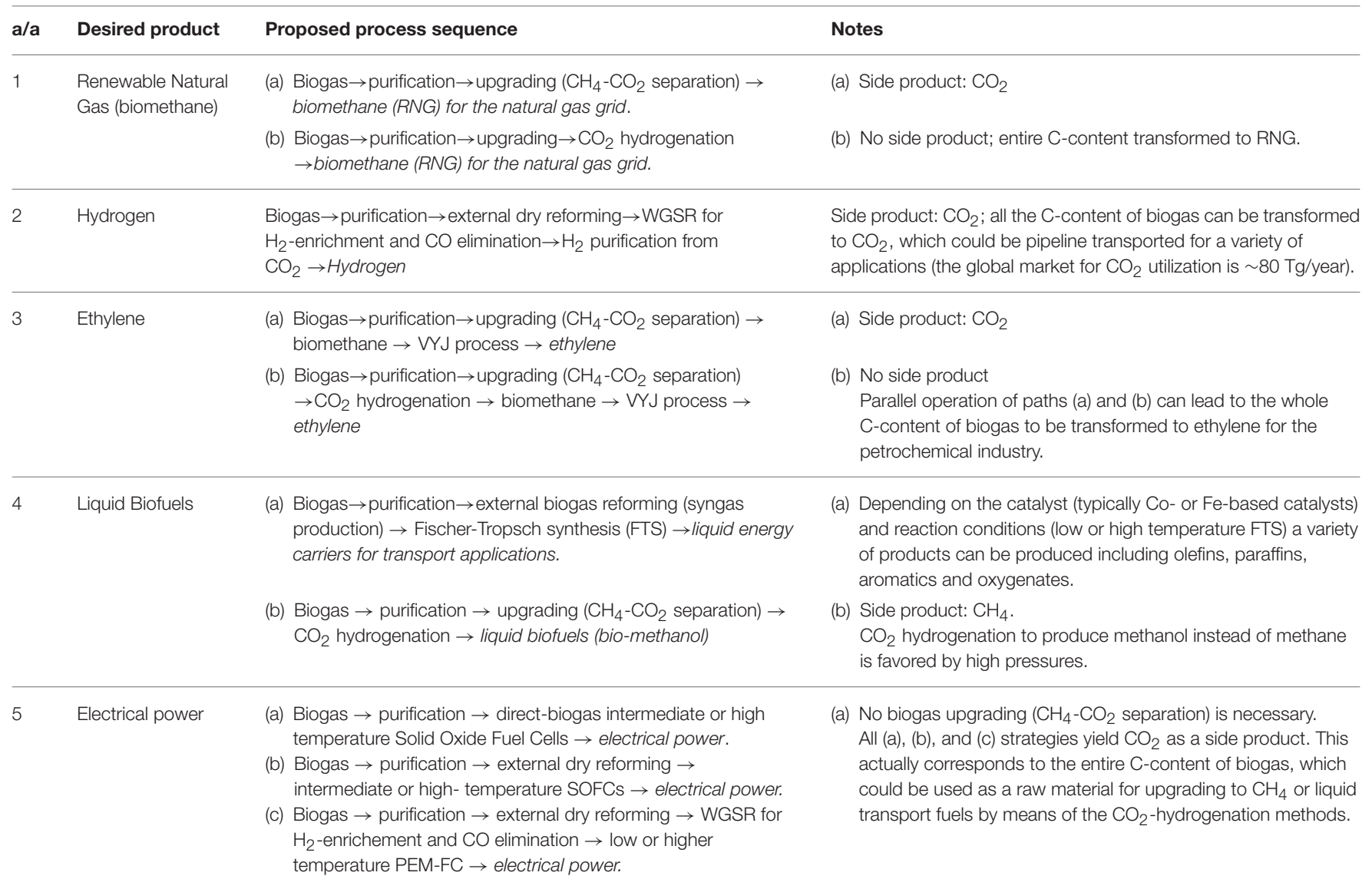

opportunity for eco-friendly and economic energy generation and production of value added chemicals.

\section{CONCLUSIONS}

Biogas, produced from the decomposition (anaerobic digestion) of all living matter, consists mainly of $\mathrm{CH}_{4}$ and $\mathrm{CO}_{2}$. Major efforts in research \& development technology are currently devoted to biogas valorization as it represents a suitable, widely available and cheap renewable carbon source, providing the opportunity for eco-friendly and economic energy generation and production of value added chemicals.

This review has focused on the exploitation of the main constituents of biogas $\left(\mathrm{CH}_{4}\right.$ and $\left.\mathrm{CO}_{2}\right)$ as potential raw materials for advanced management and exploitation of this resource, including the principal technologies available and pathways for power generation and value added chemical production.

Analysis has been provided of biogas utilization for renewable and eco-friendly electrical power generation by means of (i) low and higher temperature polymeric membrane fuel cells and (ii) intermediate and high temperature solid oxide fuel cells. In addition, processes for the conversion of biogas to (i) RNG, (ii) clean hydrogen, (iii) ethylene, and (iv) biomethanol or other Fischer-Tropsch liquid biofuels production have been examined.
A final word is in order in regard to economic evaluation of the various existing and emerging strategies for biogas exploitation, which is of course a key issue. This important subject which merits detailed discussion lies beyond the scope of our technically-oriented review, not least because most current approaches to biogas utilization are still at the research and development stage. Accordingly, there is a pressing need for comprehensive economic evaluation of alternative routes for the efficient use of biogas in the energy and chemicals sectors, including identification of bottlenecks, in order to guide policy making and future research and development in this field.

\section{AUTHOR CONTRIBUTIONS}

IY designed the review study and wrote the manuscript. GG assisted with literature searching and in discussion of the fuel cell literature data.

\section{ACKNOWLEDGMENTS}

The authors thank the Technical University of Crete-Research Committee, Special Research Funds Account, TUC, Chania, Crete, Greece, for partial financial support under the project PostDoc2016. 


\section{REFERENCES}

Abatzoglou, N., and Boivin, S. (2009). A review of biogas purification process. Biofuels Bioprod. Biorefining 3, 42-71. doi: 10.1002/bbb.117

Abe, T., Tanizawa, M., Watanabe, K., and Taguchi, A. (2009). $\mathrm{CO}_{2}$ methanation property of Ru nanoparticle-loaded $\mathrm{TiO} 2$ prepared by a polygonal barrelsputtering method. Energy Environ. Sci. 2, 315-321. doi: 10.1039/b817740f

Alonso-Vicario, A., Ochoa-Gomez, J. R., Gil-Rio, S., Gomez-JimenezAberasturi, O., Ramirez-Lopez, C. A.,Torrecilla, J., et al. (2010). Purification and upgrading of biogas by pressure swing adsorption on synthetic and natural zeolites. Microporous Mesoporous Mater. 134, 100-107. doi: 10.1016/j.micromeso.2010.05.014

Andriani, D., Wresta, A., and Atmaja, T. D. (2014). A review on optimization production and upgrading biogas through $\mathrm{CO}_{2}$ Removal Using Various Techniques. Appl. Biochem. Biotechnol. 172, 1909-1928. doi: 10.1007/s12010-013-0652-x

Ashcroft, A. T., Cheetham, A. K., Green, M. L. H., and Vernon, P. D. F. (1991). Partial oxidation of methane to synthesis gas using carbon dioxide. Nature 352, 225-226. doi: 10.1038/352225a0

Austin, G. T. (1984). Shreve's Chemical Process Industries, 5th Ed., New York, NY: McGraw-Hill.

Bagreev, A., Adib, F., and Bandosz, T. J. (2001). pH of activated carbon surface as an indication of its suitability for $\mathrm{H}_{2} \mathrm{~S}$ removal from moist air streams. Carbon 39, 1897-1905. doi: 10.1016/S0008-6223(00)00317-1

Bagreev, A., and Bandosz, T. J. (2001). $\mathrm{H}_{2} \mathrm{~S}$ adsorption/oxidation on unmodified activated carbons: importance of prehumidification. Carbon 39, 2303-2311. doi: 10.1016/S0008-6223(01)00049-5

Bansal, T., Tripathi, N., and Chawla, G. (2013). Upgradation of biogas using combined method of alkaline water scrubbing and adsoption through carbon molecular sieve. Int. J. Chem. Tech. Res. 5, 886-890.

Bashkova, S., Baker, F. S., Wu, X., Armstrong, T. R., and Schwartz, V. (2007). Activated carbon catalyst for selective oxidation of hydrogen sulphide: on the influence of pore structure, surface characteristics and catalytically-active nitrogen. Carbon 45, 1354-1363. doi: 10.1016/j.carbon.2007.01.005

Belmabkhout, Y., De Weireld, G., and Sayari, A. (2009). Amine-Bearing Mesoporous Silica for $\mathrm{CO}_{2}$ and $\mathrm{H}_{2} \mathrm{~S}$ Removal from Natural Gas and Biogas. Langmuir, 25, 13275-13278. doi: 10.1021/la903238y

Bernardo, P., Drioli, E., and Colemme, G. (2009). Membrane gas separation: A review/state of the art. Ind. Eng. Chem. Res. 48, 4638-4663. doi: $10.1021 /$ ie 8019032

Bradford, M. C. J., and Vannice, M. A. (1999). $\mathrm{CO}_{2}$ reforming of $\mathrm{CH}_{4}$. Catal. Rev. Sci. Eng. 41, 1-42. doi: 10.1081/CR-100101948

Biogas Renewable Energy (2009). Available online at: http://www.biogasrenewable-energy.info (Accessed 3, Aug. 2010)

Cabrera-Codony, A., Montes-Moran, M. A., Sanchez-Polo, M., Martin, M. J., and Gonzalez-Olmos, R. (2014). Biogas upgrading: optimal activated carbon properties for siloxane removal. Environ. Sci. Technol. 48, 7187-7195. doi: 10.1021/es501274a

Cavenati, S., Grande, C. A., Rodrigues, A. E., Keiner, C., and Muller, U. (2008). Metal organic framework adsorbent for biogas upgrading. Ind. Eng. Chem. Res. 47, 6333-6335. doi: 10.1021/ie8005269

Cebula, J. (2009). Biogas purification by sorption techniques. Architec. Civil Environ. Eng. 2, 95-103.

Chemistry and industry, I. (1994). Natural gas: chemical Engineers near "holy grail”. Chemistry \& Industry, 444.

Chung, Y.-C., Ho, K.-L., and Tseng, C.-P. (2007). Two-stage biofilter for effective $\mathrm{NH}_{3}$ removal from waste gases containing high concentrations of $\mathrm{H}_{2} \mathrm{~S}$. Air Waste Manag. Assoc. 57, 337-347. doi: 10.1080/10473289.2007.10465332

Chung, Y.-C., Huang, C., and Tseng, C.-P. (1996). Operation optimization of Thiobacillus thioparus CHll biofilter for hydrogen sulfide removal. J. Biotechnol. 52, 31-38. doi: 10.1016/S0168-1656(96)01622-7

Cosoli, P., Ferrone, M., Pricl, S., and Fermeglia, M. (2008). Hydrogen sulphide removal from biogas by zeolite adsorption. Part I. GCMC molecular simulations. Chem. Eng. J. 145, 86-92. doi: 10.1016/j.cej.2008.07.034

Croce, S., Wei, Q., D'Imporzano, G., Dong, R., and Adani, F. (2016). Anaerobic digestion of straw and corn stover: the effect of biological process optimization and pre-treatment on the total bio-methane yield and energy performance. Biotechnol. Adv. 34, 1289-1304. doi: 10.1016/j.biotechadv.2016.09.004
Dabrowski, A. (2001). Adsoprtion-from theory to practice. Adv. Colloid Interface Sci. 93, 135-224. doi: 10.1016/S0001-8686(00)00082-8

Dareioti, M. A., Dokianakis, S. N., Stamatelatou, K., Zafiri, C., and Kornaros, M. (2009). Biogas production from anaerobic co-digestion of agroindustrial wastewaters under mesophilic conditions in a two-stage process. Desalination 248, 891-906. doi: 10.1016/j.desal.2008.10.010

Das, N. K., Chaudhuri, H., Bhandari, R. K., Ghose, D., Sen, P., and Sinha, B. (2008). Purification of helium from natural gas by pressure swing adsorption. Curr. Sci. 95, 1684-1687.

de Arespacochaga, N., Valderrama, C., Raich-Montiu, J., Crest, M., Mehta, S., and Cortina, J. L. (2015). Understanding the effects of the origin, occurrence, monitoring, control, fate and removal of siloxanes on the energetic valorization of sewage biogas-A Review. Renewable Sust. Energy Rev. 52, 366-381. doi: 10.1016/j.rser.2015.07.106

Deng, L., and Hagg, M.-B. (2010). Techno-economic evaluation of biogas upgrading process using $\mathrm{CO}_{2}$ facilitated transport membrane. Int. J. Greenhouse Gas Control 4, 683-646. doi: 10.1016/j.ijggc.2009.12.013

Dewil, R., Appels, L., and Baeyens, J. (2006). Energy use of biogas hampered by the presence of siloxanes. Energy Convers. Manag. 47, 1711-1722. doi: 10.1016/j.enconman.2005.10.016

Diaz, I., Ramos, I., and Fdz-Polanco, M. (2015). Economic analysis of microaerobic removal of $\mathrm{H}_{2} \mathrm{~S}$ from biogas in full-scale sludge digesters. Bioresour. Technol. 192, 280-286. doi: 10.1016/j.biortech.2015.05.048

Elias, A., Barona, A., Arreguy, A., Rios, J., Aranguiz, I., and Penas, J. (2002). Evaluation of a packing material for the biodegradation of $\mathrm{H}_{2} \mathrm{~S}$ and product analysis. Process Biochem. 37, 813-820. doi: 10.1016/S0032-9592(01)00287-4

Favre, E., Bounaceur, R., and Roizard, D. (2009). Biogas, membranes and carbon dioxide capture. J. Memb. Sci. 328, 11-14. doi: 10.1016/j.memsci.2008.12.017

Fernandez, M., Ramirez, M., Perez, R. M., Gomez, J. M., and Cantero, D. (2013). Hydrogen sulphide removal from biogas by an anoxic biotrickling filter packed with Pall rings. Chem. Eng. J. 225, 456-463. doi: 10.1016/j.cej.2013.04.020

Fortuny, M., Baeza, J. A., Gamisans, X., Casas, C., Lafuente, J., Deshusses, M. A., et al. (2008). Biological sweetening of energy gases mimics in biotrickling filters. Chemosphere 71, 10-17. doi: 10.1016/j.chemosphere.2007.10.072

Fuerte, A., Valenzuela, R. X., Escudero, M. J., and Daza, L. (2014). Study of a SOFC with a bimetallic Cu-Co-ceria anode directly fuelled with simulated biogas mixtures. Int. J. Hydrogen Energy 39, 4060-4066. doi: 10.1016/j.ijhydene.2013.06.142

Ganesh, I. (2014). Conversion of carbon dioxide into methanol - a potential liquid fuel: fundamental challenges and opportunities (a review). Renewable Sustainable Energy Rev. 31, 221-257. doi: 10.1016/j.rser.2013.11.045

Geormezi, M., Chochos, C. L., Gourdoupi, N., Neophytides, S., and Kallitsis, J. K. (2011). High performance Polymer electrolytes based on main and side chain pyridine aromatic polyethers for high and medium temperature proton exchange membrane fuel cells. J. Power Sources 196, 9382-9390. doi: 10.1016/j.jpowsour.2011.06.031

Geormezi, M., Deimede, V., Kallitsis, J. K., and Neophytides, S. (2012). Polymer blends based on copolymers bearing both side and main chain pyridine units as proton exchange membranes for high temperature fuel cells. J. Memb. Sci. 396, 57-66. doi: 10.1016/j.memsci.2011.12.039

Goula, G., Kiousis, V., Nalbandian, L., and Yentekakis, I. V. (2006). Catalytic and electrocatalytic behavior of Ni-based cermet anodes under internal dry reforming of $\mathrm{CH}_{4}+\mathrm{CO}_{2}$ mixtures in SOFCs. Solid State Ionics 177, 2119-2123. doi: $10.1016 /$ j.ssi.2006.03.040

Grande, C. A. (2011). "Biogas upgrading by pressure swing adsorption (Chapter 3)," in Biofuel's Engineering Process Technology, ed M. A. Dos Santos Bernardes (InTech). Available online at: http://www.intechopen.com/books/biofuels-engineering-process-technology/biogas-upgrading-by-pressure-swingadsorption

Grande, C. A. (2012). Review Article: advances in pressure swing adsorption for gas separation. ISRN Chem. Eng. 2012, 13. doi: 10.5402/2012/982934

Grande, C. A., and Rodrigues, A. E. (2007). Biogas to fuel by vacuum pressure swing adsorption I. behavior of equilibrium and kinetic adsorbents. Ind. Eng. Chem. Res., 46, 4595-4605. doi: 10.1021/ie061341+

Guerra, C., Lanzini, A., Leone, P., Santareli, M., and Beretta, D. (2013). Experimental study of dry reforming of biogs in a tubular anode-supported solid oxide fuel cell. Int. J. Hydrogen Energy 38, 10559-10566. doi: 10.1016/j.ijhydene.2013.06.074 
Guerra, C., Lanzini, A., Leone, P., Santareli, M., and Brandon, N. P. (2014). Optimization of dry reforming of methane over Ni/YSZ anodes for solid oxide fuel cells. J. Power Sources 245, 154-163. doi: 10.1016/j.jpowsour.2013.06.088

Gur, T. M. (2016). Comprehensive review of methane conversion in solid oxide fuel cells: prospects for efficient electricity generation from natural gas. Progr. Energy Combust. Sci. 54, 1-64. doi: 10.1016/j.pecs.2015. 10.004

Habisreutinger, S. N., Schmidt-Mente, L., and Stolarczyk, J. K. (2013). Photocatalytic reduction of $\mathrm{CO}_{2}$ on $\mathrm{TiO} 2$ and other semiconductors. Angew. Chem. Int. Ed. 52, 7372-7408. doi: 10.1002/anie.201207199

Haga, K., Adachi, S., Shiratori, Y., Itoh, K., and Sasaki, K. (2008). Poisoning of SOFC anodes by various fuel impurities. Solid State Ionics 179, 1427-1431. doi: 10.1016/j.ssi.2008.02.062

Helbio, S. A. Hydrogen and Energy Production Systems. Available online: http:// helbio.com

Higgins, V. L. (2007). Siloxane Removal Process. US Patent 7,306,652, Assignee Parker-Hannifin Corporation. Issued on December 11, 2007.

Himeno, S., Komantsu, T., and Fujita, S. (2005). High-pressure adsorption equilibria of methane and carbon dioxide on several activated carbons. J. Chem. Eng. Data 50, 369-376. doi: 10.1021/je049786x

Ho, K.-L., Lin, W.-C., Chung, Y.-C., Chen, Y.-P., and Tseng, C.-P. (2013). Elimination of high concentration hydrogen sulfide and biogas purification by chemical-biological process. Chemosphere 92, 1396-1401. doi: 10.1016/j.chemosphere.2013.05.054

Hoffmann, M. R., Moss, J. A., and Baum, M. M. (2011). Artificial Photosynthesis: semiconductor photocatalitic fixation of $\mathrm{CO}_{2}$ to afford higher organic compounds. Dalton Trans. 40, 5151-5158. doi: 10.1039/c0dt01777a

Ito, T., and Lunsford, J. H. (1985). Synthesis of ethylene and ethane by partial oxidation of methane over lithium-doped magnesium oxide. Nature 314, 721-722. doi: 10.1038/314721b0

Jadhav, S. G., Vaidya, P. D., Bhanage, B. M., and Joshi, J. B. (2014). Catalytic carbon dioxide hydrogenation to methanol: a review of recent studies. Chem. Eng. Res. Des. 92, 2557-2567. doi: 10.1016/j.cherd.2014.03.005

Jafari, T., Jiang, T., Zhong, W., Khakpash, N., Deljioo, B., Aindow, M., et al. (2016). Modified mesoporous silica for efficient siloxane capture. Langmuir 32, 2369-2377. doi: 10.1021/acs.langmuir.5b04357

Jalali, A., Motamedhashemi, M. M. Y., Egolfopoulos, F., and Tsotsis, T. (2013). Fate of siloxane impurities during the compustion of renewable natural gas. Comb. Sci. Techn. 185, 953-974. doi: 10.1080/00102202.2013.766606

Janardhanan, V. M. (2015a). Internal reforming of biogas in SOFC: a model based investigation. J. Solid State Electrochem. 19, 2981-2990. doi: 10.1007/s10008-015-2909-5

Janardhanan, V. M. (2015b). Multi-scale modeling of biogas fueled SOFC. ECS Trans. 68, 3051-3058. doi: 10.1149/06801.3051ecst

Jee, J. G., Lee, J. S., and Lee, C. H. (2001). Air separation by a small-scale two-bed medical O2 pressure swing adsorption. Ind. Engin. Chem. Res. 40, 3647-3658. doi: 10.1021/ie0101011

Jeníček, P., Horejš, J., Pokorná-Krayzelová, L., Bindzar, J., and Bartáček, J. (2017). Simple biogas desulfurization by microaeration-Full scale experience. Anaerobe doi: 10.1016/j.anaerobe.2017.01.002. [Epub ahead of print].

Jiang, T., Zhong, W., Jafari, T., Du, S., He, J., Fu, Y.-J., et al. (2016). Siloxane D4 adsorption by mesoporous aluminosilicates. Chem. Engin. J. 289, 356-364. doi: 10.1016/j.cej.2015.12.094

Jiang, Y., Yentekakis, I. V., and Vayenas, C. G. (1994). Methane to Ethylene with 85 percent yield in a gas recycle electrocatalytic reactor-separator. Science 264, 1563-1566. doi: 10.1126/science.264.5165.1563

Kao, C.-Y., Chiu, S.-Y., Huang, T.-T., Dai, L., Hsu, L.-K., and Lin, C.S. (2012). Ability of a mutant strain of the microalga Chlorella sp. To capture carbon dioxide for biogas upgrading. Appl. Energy 93, 176-183. doi: 10.1016/j.apenergy.2011.12.082

Keller, G. E., and Bhasin, M. M. (1982). Synthesis of ethylene via oxidative coupling of methane. I. Determination of active catalysts. J. Catal. 73, 9-19. doi: 10.1016/0021-9517(82)90075-6

Khalil, M. J., Sharma, K., and Gupta, R. (2014). “Strategic Technologies for biogas purification," in International journal of Engineering and Technical Research ISSN: 2321-0869, Special Issue. National Conference on Synergetic trends in Engineering and Technology (STET-2014). Available online at: http://www. erpublication.org
Kim, S., and Deshusses, M. A. (2005). Understanding the limits of $\mathrm{H}_{2} \mathrm{~S}$ degrading biotrickling filters using a differential biotrickling filter. Chem. Eng. J. 113, 119-126. doi: 10.1016/j.cej.2005.05.001

Kismurtono, M. (2011). Upgrade biogas purification in packed column with chemical absorption of $\mathrm{CO}_{2}$ for energy alternative of small industry (UKMTahu). Int. J. Eng. Technol. IJET-IJENS 11, 83-86.

Kobayashi, T., Li, Y.-Y., Kubota, K., Harada, H., Maeda, T., and Yu, H.-Q. (2012). Characterization of sulfide-oxidizing microbial mats developed inside a full-scale anaerobic digester employing biological desulfurization. Appl. Microbiol. Biotechnol. 93, 847-857. doi: 10.1007/s00253-0113445-6

Kohl, A. L., and Nielsen, R. B. (1997). "Chapter 2: alkanolamines for hydrogen sulfide and carbon dioxide removal," in Gas Purification, 5th Ed. (Houston, TX: Goulf Professional Publishing).

Kwansy, J., and Balcerzak, W. (2016). Sorbents used for biogas desulfurization in the adsorption process. Pol. J. Environ. Stud. 25, 37-43. doi: $10.15244 /$ pjoes/60259

Lanzini, A., and Leone, P. (2010). Experimental investigation of direct internal reforming of biogas in solid oxide fuel cells. Int. J. Hydrogen Energy 35, 2463-2476. doi: 10.1016/j.ijhydene.2009.12.146

Lanzini, A., Leone, P., Guerra, C., Smeacceto, F., Brandon, N. P., and Santarelli, M. (2013). Durability of anode supported solid oxides fuel cells (SOFC) under direct dry-reforming of methane. Chem. Eng. J. 220, 254-263. doi: 10.1016/j.cej.2013.01.003

Lanzini, A., Leone, P., Pieroni, M., Santarelli, M., Beretta, D., and Ginocchio, S. (2011). Experimental investigation and modeling of direct internal reforming of biogases in tubular solid oxide fuel cells. Fuel Cells 11 697-710. doi: 10.1002/fuce.201000173

Lin, W.-C., Chen, Y.-P., and Tseng, C.-P. (2013). Pilot-scale chemical-biological system for efficient $\mathrm{H}_{2} \mathrm{~S}$ removal from biogas. Bioresour. Technol. 135, 283-291. doi: 10.1016/j.biortech.2012.10.040

Lohwacharin, J., and Annachhatre, A. P. (2010). Biological sulfide oxidation in an airlift bioreactor. Bioresour. Technol. 101, 2114-2120. doi: 10.1016/j.biortech.2009.10.093

Lunsford, J. H. (1990). The catalytic conversion of methane to higher hydrocarbons. Catal. Today 6, 235-259. doi: 10.1016/0920-5861(90)85004-8

Ma, J., Jiang, C., Connor, P. A., Cassdy, M., and Irvine, J. T. S. (2015). High efficient, coking-resistant SOFCs for energy conversion using biogas fuels. J. Mater. Chem. A 3, 19068-19076. doi: 10.1039/C5TA06421J

Ma, S., Sun, D., Wang, X.-S., and Zhou, H.-C. (2007). A Mesh-Adjustable molecular sieve for general use in gas separation. Angew. Chem. Int. Ed. 46, 2458-2462. doi: 10.1002/anie.200604353

Madi, H., Lanzini, A., Diethelm, S., Papullero, D., van Herle, J., Lualdi, M., et al. (2015). Solid oxide fuel cell anode degradation by the effect of siloxanes. $J$. Power Sources 279, 460-471. doi: 10.1016/j.jpowsour.2015.01.053

Makaruk, A., Miltner, M., and Harasek, M. (2010). Membrane biogas upgrading processes for the production of natural gas substitute. Separat. Purif. Technol. 74, 83-92. doi: 10.1016/j.seppur.2010.05.010

Makri, M., Jiang, Y., Yentekakis, I. V., and Vayenas, C. G. (1996). Oxidative Coupling of Methane to Ethylene with $85 \%$ Yield in a Gas Recycle Electrocatalytic or Catalytic Reactor Separator. Stud. Surf. Sci. Catal. 101, 287-395.

Mao, C., Feng, Y., Wang, X., and Ren, G. (2015). Review on research achievements of biogas from anaerobic digestion. Renewable Sustainable Energy Rev. 45, 540-555. doi: 10.1016/j.rser.2015.02.032

Micoli, L., Bagnasco, G., and Turco, M. (2014). $\mathrm{H}_{2} \mathrm{~S}$ removal from biogas for fuelling MCFCs: new adsorbing materials. Int. J. Hydrogen Energy 34, 1783-1787. doi: 10.1016/j.ijhydene.2013.10.126

Montanari, T., Finocchio, E., Bozzano, I., Garuti, G., Giordano, A., Pistarino, C., et al. (2010). Purification of landfill biogases from siloxanes by adsorption: a study of silica and $13 \mathrm{X}$ zeolite adsorbents on hexamethylcyclotrisiloxane separation. Chem. Eng. J. 165, 859-863. doi: 10.1016/j.cej.2010. 10.032

Nair, N., Vas, A., Zhu, T., Sun, W., Gutierrez, J., Chen, J., et al. (2013). Effect of siloxanes contained in natural gas on the operation of a residential furnace. Ind. Eng. Chem. Res. 52, 6553-6261. doi: 10.1021/ie400449y

Nair, N., Zhang, X., Guteierrez, J., Chen, J., Egolfopoulos, F., and Tsotsis, T. (2012). Impact of siloxane impurities on the performance of an engine 
operating on renewable natural gas. Indus. Eng. Chem. Res. 51, 15786-15795. doi: $10.1021 /$ ie302751n

Ni, M. (2013). Modeling and parametric simulations of solid oxide fuel cells with methane carbon dioxide reforming. Energy Conversion Manag. 70, 116-129. doi: 10.1016/j.enconman.2013.02.008

Niakolas, D. K., Neophytides, C., Neophytides, N. G., Tsiplakides, D., Papazisi, K.-M., and Balomenou, S. (2015). Carbon tolerant electrodes for SOFC and reversible SOFC (RSOFC) cells operating on carbon containing fuels. ECS Trans. 68, 3439-3447. doi: 10.1149/06801.3439ecst

Nikolaidou, E., Iossifidou, M., Yentekakis, I. V., Goula, G., Aivasidis, A., Diamantis, V., et al. (2015). "Energy production and winery organic bybroduct treatment," in Proceedings of the 5th International Conference on Environmental Management Engineering, Planning and Economics (CEMEPE2015) (Mykonos).

Ohannessian, A., Desjardin, V., Chatain, V., and Germain, P. (2008). Volatile organic silicon compounds: the most undesirable contaminants in biogases. Waste Sci. Technol. 58, 1775-1781. doi: 10.2166/wst.20 08.498

Osorio, F., and Torres, J. C. (2009). Biogas purification from anaerobic digestion in a wastewater treatment plant for biofuel production. Renewable Energy 34, 2164-2171. doi: 10.1016/j.renene.2009.02.023

Oyarzun, P., Arancibia, F., Canales, C., and Aroca, G. E. (2003). Biofiltration of high concentration of hydrogen sulphide using Thiobacillus thioparus. Process Biochem. 39, 165-170. doi: 10.1016/S0032-9592(03)0 0050-5

Pandey, D. R., and Fabian, C. (1989). Feasibility studies on the use of naturally accruing molecular sieves for methane enrichment from biogas. Gas Sep. Purif. 3, 143-147. doi: 10.1016/0950-4214(89)80026-X

Papadam, T., Goula, G., and Yentekakis, I. V. (2012). Long-term operation stability tests of intermediate and high temperature Ni-based anodes' SOFCs directly fueled with simulated biogas mixtures. Int. J. Hydrogen Energy 37, 16680-16685. doi: 10.1016/j.ijhydene.2012.02.147

Papadopoulou, C., Matralis, H., and Verykios, X. (2012). "Utilization of biogas as a renewable carbon source: dry reforming of methane," in Catalysis for Alternative Energy Generation, eds L. Guczi, and A. Erdohelyi (New York, NY: Springer Science+Busines Media), 57-127.

Perry, R. H., Green, D. W., and Maloney, J. O. (1984). Perry's Chemical Engineers' Handbook, 6th Edn. New York, NY: McGraw-Hill, Inc.

Petersson, A., and Wellinger, A. (2009). "Biogas upgrading technologiesdevelopments and innovations," in Task 37-Energy from Biogas and Landfill Gas (IEA Bioenergy), Available online at: http://www.iea-biogas.net/files/datenredaktion/download/publi-task37/upgrading_rz_low_final.pdf (Accessed: 6, Sept 2010)

Pipatmanomai, S., Kaewluan, S., and Vitidsant, T. (2009). Economic assessment of Biogas-to-electricity generation system with $\mathrm{H}_{2} \mathrm{~S}$ removal by activated carbon in small pig farm. Appl. Energy, 86, 669-674. doi: 10.1016/j.apenergy.2008.07.007

Puga, A. V. (2016). Light-promoted hydrogenation of carbon dioxide-an overview. Top. Catal. 59, 1268-1278. doi: 10.1007/s11244-016-0658-z

Ramos, I., Pena, M., and Fdz-Polanco, M. (2014b). Where does the removal of $\mathrm{H}_{2} \mathrm{~S}$ from biogas occur in microaerobic reactors? Bioresour. Technol. 166, 151-157. doi: 10.1016/j.biortech.2014.05.058

Ramos, I., Perez, R., and Fdz-Polanco, M. (2014a). The headspace of microaerobic reactors: sulphide-oxidising population and the impact of cleaning on the efficiency of biogas desulphurization. Bioresour. Technol. 158, 63-73. doi: 10.1016/j.biortech.2014.02.001

Rodriguez, G., Dorado, A. D., Fortuny, M., Gabriel, D., and Gamisans, X. (2014). Biotrickling filters for biogas sweetening: oxygen transfer improvement for a reliable operation. Proc. Saf. Environ. Prot. 92, 261-268. doi: 10.1016/j.psep.2013.02.002

Rostrup-Nielsen, J. R., and Hansen, J.-H. B. (1993). $\mathrm{CO}_{2}$-reforming of methane over transition metals. J. Catal. 144, 38-49. doi: 10.1006/jcat.1993.1312

Roy, S. C., Varghese, O. K., Paulose, M., and Grimes, C. A. (2010). Towards solar fuels: photocatalytic conversion of carbon dioxide to hydrocarbons. ACS Nano 4, 1259-1278. doi: 10.1021/nn9015423

Ryckebosch, E., Drouillon, M., and Vervaeren, H. (2011). Techniques for transformation of biogas to biomethane. Biomass Bioenergy 35, 1633-1645. doi: 10.1016/j.biombioe.2011.02.033
Saeidi, S., Amin, N. A. S., and Rahimpour, M. R. (2014). Hydrogenation of $\mathrm{CO}_{2}$ to value-added products-A review and potential future developments. J. $\mathrm{CO}_{2}$ Util. 5, 66-81. doi: 10.1016/j.jcou.2013.12.005

Salihu, A., and Alam, M. D. Z. (2015). Upgrading strategies for effective utilization of biogas. AIChE, Environ. Progr. Sustainable Energy 34, 1512-1520. doi: $10.1002 /$ ep. 12117

Schulz, H. (1999). Short history and present trends of Fischer-Tropsch synthesis. Appl. Catal. A 186, 3-12. doi: 10.1016/S0926-860X(99)00160-X

Selvatico, D., Lanzini, A., and Santarelli, M. (2016). Low temperature FischerTropsch fuels from syngas: kinetic modeling and process simulation of different plant configurations. Fuel 186, 544-560. doi: 10.1016/j.fuel.2016.08.093

Shiratori, Y., Ijchi, T., Oshima, T., and Sasaki, K. (2010). Internal reforming SOFC running on biogas. Inter. J. Hydrog. Energy 35, 7905-7912. doi: 10.1016/j.ijhydene.2010.05.064

Shiratori, Y., Oshima, T., and Sasaki, K. (2008). Feasibility of direct-biogas SOFC. Int. J. Hydrog. Energy 33, 6316-6321. doi: 10.1016/j.ijhydene.2008.07.101

Schweigkofler, M., and Niessner, R. (2001). Removal of siloxanes in biogases. J. Hazard. Mater. B 83, 183-196. doi: 10.1016/S0304-3894(00)00318-6

Sigot, L., Ducom, G., Benadda, B., and Laboure, C. (2014). Adsorption of octamethylcyclotetrasiloxane on silica gel for biogas purification. Fuel 135, 205-209. doi: 10.1016/j.fuel.2014.06.058

Simons, K., Nijmeijer, K., and Wessling, M. (2009). Gas-liquid membrane contactors for $\mathrm{CO}_{2}$ removal. J. Membr. Sci. 340, 214-220. doi: 10.1016/j.memsci.2009.05.035

Sorokin, D. Y., van den Bosch, P. L. F., Abbas, B., Janssen, A. J. H., and Muyzer, G. (2008). Microbiological analysis of the population of extremely haloalkaliphilic sulfur-oxidizing bacteria dominating in lab-scale sulfide-removing bioreactors. Appl. Microbiol. Biotechnol. 80, 965-975. doi: 10.1007/s00253-008-1598-8

Stamatelatou, K., Antonopoulou, G., and Lyberatos, G. (2010). "Chapter 12Production of biogas via anaerobic digestion," in Handbook of Biofuels Production: Processes and Technologies, eds R. Luque, J. Campelo, and J. Clark (Granta Park: Woodhead Publishing Limited), 266-304.

Stamatelatou, K., Antonopoulou, G., Ntaikou, I. and Lyberatos, G. (2012). "The effect of physical, chemical, and biological pretreatments of biomass on its anaerobic digestibility and biogas production," in Biogas Production: Pretreatment Methods in Anaerobic Digestion, ed A. Mudhoo (Hoboken, NJ: John Wiley \& Sons, Inc.), 55-90. doi: 10.1002/9781118404089.ch3

Sun, Q., Li, H., Yan, J., Liu, L., Yu, Z., and Yu, X. (2015). Selection of appropriate biogas upgrading technology-a review of biogas cleaning, upgrading and utilization. Renewable Sustainable Energy Rev. 51, 512-532. doi: 10.1016/j.rser.2015.06.029

Syed, M., Soreanu, G., Falletta, P., and Beland, M. (2006). Removal of hydrogen sulfide from gas streams using biological processes - a review. Can. Biosys. Eng. 48, 2.1-2.14.

Takahashi, Y., Shiratori, Y., Furuta, S., and Sasaki, K. (2012). Thermo-mechanical reliability and catalytic activity of Ni-Zirconia anode supports in internal reforming SOFC running on biogas. Solid State Ionics 225, 113-117. doi: 10.1016/j.ssi.2012.03.038

Tang, K., Baskaran, V., and Nemati, M. (2009). Bacteria of the sulphur cycle: an overview of microbiology, biokinetics and their role in petroleum and mining industries. Biochem. Eng. J. 44, 73-94. doi: 10.1016/j.bej.2008.12.011

Tippayawong, N., and Thanompongchart, P. (2010). Biogas quality upgrade by simultaneous removal of $\mathrm{CO}_{2}$ and $\mathrm{H}_{2} \mathrm{~S}$ in a packed column reactor. Energy 35, 4531-4535. doi: 10.1016/j.energy.2010.04.014

Van Den Bosch, P. L. F., Sorokin, D. Y., Buisman, C. J. N., and Janssen, A. J. H. (2008). The effect of $\mathrm{pH}$ on thiosulfate formation in a biotechnological process for the removal of hydrogen sulfide from gas streams. Environ. Sci. Technol. 42, 2637-2642. doi: 10.1021/es7024438

Vayenas, C. G., Yentekakis, I. V., and Jiang, Y. (1995). Method and Apparatus for Forming Ethylene or Ethane and Ethylene from Methane. PCT Patent, WO9520556 (A1) - 1995-08-03.

Verykios, X. E. (2003). Catalytic dry reforming of natural gas for the production of chemicals and hydrogen. Int. J. Hydrog. Energy 28, 1045-1063. doi: 10.1016/S0360-3199(02)00215-X

Wang, W., Su, C., Ran, R., Park, H. J., Kwak, C., and Shao, Z. (2011a). Physically mixed LiLaNi- $\mathrm{Al}_{2} \mathrm{O}_{3}$ and copper as conductive anode catalysts in a solid oxide fuel cell for methane internal reforming and partial oxidation. Inter. J. Hydrogen Energy 36, 5632-5643. doi: 10.1016/j.ijhydene.2011.01.163 
Wang, W., Su, C., Wu, Y., Ran, R., and Shao, Z. (2013). Progress in solid oxide fuel cells with Nickel-based anodes operating on methane and related fuels. Chem. Rev. 113, 8104-8151. doi: 10.1021/cr300491e

Wang, W., Wang, S., Ma, X., and Gong, J. (2011b). Recent advances in catalytic hydrogenation of carbon dioxide. Chem. Soc. Rev. 40, 3703-3727. doi: $10.1039 / \mathrm{clcs} 15008 \mathrm{a}$

Weiland, P. (2010). Biogas production: current state and perspectives. Appl. Microbiol. Biotechnol. 85, 849-860. doi: 10.1007/s00253-009-2246-7

Wellinger, A., and Lindberg, A. (2005). "Biogas upgrading and utilization," in IEA Bioenergy Task 24: Energy from Biological Conversion of Organic Waste. Available online at: http://www.biogasmax.eu/media/biogas_upgrading-and_ utilization_0180031200_1011_24042007.pdf

Xiao, Y., Wang, S., Wu, D., and Yuan, Q. (2008). Catalytic oxidation of hydrogen sulfide over unmodified and impregnated activated carbon. Separat. Purif. Technol. 59, 326-332. doi: 10.1016/j.seppur.2007.07.042

Yang, R. T. (2003). Adsorbents: Fundamentals and Applications. Hoboken, NJ: John Wiley and Sons.

Yentekakis, I. V. (2006). Open- and closed-circuit study of an intermediate temperature SOFC directly fueled with simulated biogas mixtures. J. Power Sources 160, 422-425. doi: 10.1016/j.jpowsour.2005.12.069

Yentekakis, I. V., Goula, G., Panagiotopoulou, P., Katsoni, A., Diamantopoulos, E., Mantzavinos, D., et al. (2015). Dry reforming of methane: catalytic performance and stability of $\mathrm{Ir}$ catalysts supported on $\gamma$ - $\mathrm{Al} 2 \mathrm{O} 3, \mathrm{Zr} 0.92 \mathrm{Y} 0.08 \mathrm{O} 2-\delta$ (YSZ) or Ce0.9Gd0.1O2- $\delta$ (GDC) supports. Top. Catal. 58, 1228-1241. doi: $10.1007 / \mathrm{s} 11244-015-0490-\mathrm{x}$
Yentekakis, I. V., Jiang, Y., Makri, M., and Vayenas, C. G. (1995). Ethylene Production from Methane in a Gas Recycle Electrocatalytic Reactor Separator. Ionics 1, 286-291. doi: 10.1007/BF02390209

Yentekakis, I. V., Makri, M., Jiang, Y., and Vayenas, C. G. (1996). "A novel gas-recycle reactor-separator for the oxidative coupling of Methane," in ACS division of Petroleum Chemistry Inc. Vol. 41. (American Chemical Society), 119-124.

Yentekakis, I. V., Papadam, T., and Goula, G. (2008). Electricity production from wastewater treatment via a novel biogas-SOFC aided process. Solid State Ionics 179, 1521-1525. doi: 10.1016/j.ssi.2007.12.049

Yuan, B., Wu, X., Chen, Y., Huang, J., Luo, H., and Deng, S. (2013). Adsorption of $\mathrm{CO}_{2}, \mathrm{CH}_{4}$ and $\mathrm{N}_{2}$ on ordered mesoporous carbon: approach for greenhouse gases capture and biogas upgrading. Environ. Sci. Techn. 47, 5474-5480. doi: $10.1021 / \mathrm{es} 4000643$

Conflict of Interest Statement: The authors declare that the research was conducted in the absence of any commercial or financial relationships that could be construed as a potential conflict of interest.

Copyright (c) 2017 Yentekakis and Goula. This is an open-access article distributed under the terms of the Creative Commons Attribution License (CC BY). The use, distribution or reproduction in other forums is permitted, provided the original author(s) or licensor are credited and that the original publication in this journal is cited, in accordance with accepted academic practice. No use, distribution or reproduction is permitted which does not comply with these terms. 